University of Rhode Island

DigitalCommons@URI

Open Access Master's Theses

1964

\title{
From Federalist to Whig: The Political Career of Tristam Burges
}

Thomas John Sullivan

University of Rhode Island

Follow this and additional works at: https://digitalcommons.uri.edu/theses

\section{Recommended Citation}

Sullivan, Thomas John, "From Federalist to Whig: The Political Career of Tristam Burges" (1964). Open Access Master's Theses. Paper 1804.

https://digitalcommons.uri.edu/theses/1804

This Thesis is brought to you for free and open access by DigitalCommons@URI. It has been accepted for inclusion in Open Access Master's Theses by an authorized administrator of DigitalCommons@URI. For more information, please contact digitalcommons-group@uri.edu. 


\section{FROM FEDERALIST TO VHTG: \\ THE POLITTCAL CAREER OF TRISTAM BURGES}

BY

THOMAS JOEN GULLIVAN

A THESIS SUBMTTTED IN PARTEAL FULFILLMENT OF THE REQUIREMENTS FOR THE. DEGREE OF MASTER OF ARTS

IN

HISTORX 


\section{ACKNOWLEDGHENT}

The author wishes to express his gratitude to vr. Willian Dewitt Hetz of the Univensity of inhode Island Hittory Department for his guidance in the preparation of this thesis. His wide knowledge of Rhode Island history and bibliographical aids proved an invaluable asset. Appreciation is also extended to Mr. Clarkson Collins, III and his staff at the Rhode Islana Historical Society for thein hely in locmting needed manuscript materials.

Lastly, the author wishes to express his gratitude to his wife, Marguerite C. Sullivan. Her patience and inspiration mads the writing of this thesis a much Iignter task than it otherwise would have been. 


\section{ABSTRACT}

Tristan Burges was born in Roohester, Massachusetts, on February 26, 1770. After beginning his educational career rather late in life, he entered Brown University as a sophomore in 1793. A fine student, he was chosen to deliver the class valedictory address in 1796 . Burges then settled down to practice law in his adopted state.

Through his law practice Burges becane well known in Providence and interested in local politics. He took the Federalist Party stand in opposition to Jefferson's economic policies before the war of 1812. In 1811 he was elected to the State House of Representatives. He served one term and resigned in 2812 after being reelected. In May, 1817 he was chosen by the State Grand Committee as Chief Justice of the Rhode Island Supreme Court. After a year of service he was replaced by the Republicans when his party fell out of power.

In 1825 Burges was nominated to mun for Congress by the Federalist element in the Republican Party. This nomination was made possible when Job Durfee, an incumbent Congressman who failed renomination, bolted the party and ran as an Independent. In the ensuing election Burges polled the highest number of votes and was elected. This began a career in Congress that was to span a ten year period, for he was 
consistently reelected until 1835 .

In Congress Burges ardently defended Rhode Island from the attacks of the south. His most vehement clashes came with Congressinan George MacDuffie of South Caralina over the tariff. Burges, influenced by family connections in the Rhode Island woolen industry as well as by the needs of the state, fought for a high protective tariff. He supported the Tariff of Abominations in 1828 and the bill of 1830 . Over the compromise lowering of the tariff in 1833 , however, he denounced Henry $\mathrm{Clay}$ and voted against the measure. His later years in Congress might be termed the anti-Jackson years. With the exception of the nullification controversy, Burges was in constant opposition to the President. This is especially true in the controversy over the Bank of the United States and the French spoilation claims. The bank controversy also caused Burges to break with his fellow Rhode Island Congressman, Dutee J. Pearce. This had political reperoussions at home.

As a member of the anti-Jackson forces, it was easy for Burges to follow the general shift into the Whig Party. In 1835 he ran as a Whig for his sixth term in Congress but was beaten by a narrow margin. Along with his break with Pearee, this defeat may be attributed to a general decline of hig popularity at that time. In 1836 Burges ran as a 
Whig for the governorship, and was again defeated. After this defeat Burges' only political activity cccurred in 1839 when he lost in a race for the governorship. Burges had not wanted to run in this election, but was put forth agalnat his will by Whigs who were dissatisfied with the existing adrinistration. After this final defeat in 1839 , Burges retired to his family farm in Seekonk, Massachusetts, where he lived in partial seclusion. Tristam Burges died at his horn on Ootober 13, 2853, in his eighty-thind year. He was buxied in Providence-uthe town he had represented for many years. 


\section{TABLE OF CONTENTS}

CHAPTER

PAGE

ABSTRACI . . ....................

I. A CAREER BEGINS: THE EMERGENCE OF A FEDERALIST

II. A NATIONAL REPUBLICAN TO CONGRESS . . .

III. LATER ADAMS YEARS, THE TARIFF OF 1828 . .

IV. THE JACKSON YEARS . . . . . . . . .

V. A WHIG IS DEFEATED: THE ELECTIONS OF 1835 AND $2835, \cdot, \cdot, \cdot, \cdot, \cdot, \cdot \cdot \cdot \cdot$

VI. THE BALD EAGLE PASSES ............. 
A CAREER BEGINS: THE EMERGENCE OF A FEDERALIST

A common feeling among many leading Americans of the early $1730^{\prime} \mathrm{s}$ was the hope that political parties would not develop. Although men like Washington, Jefferson, Hamilton, and Madison felt that political parties stood mainly for selfsatisfaction and personal maneuver, the impulse toward political organization was inexorable. Indeed, the man who perhaps unwittingly began political parties was Washington's Secretary of the Treasury, Alexander Hamilton. Through his organization of congressional support for such measures as a national bank and the assumption of state debts, the Secretary not only was able to gain the adoption of his program, but he also brought about the organization of an opposition-which in time came to be known as the Republicans. Gradually during the $1790^{\prime}$ 's these Republicans built their strength in the states and districts, and actively campaigned on party tickets in 1796. By the end of Washington's second term the United States had its first national party in the Republicans. The Federalists, original supporters of hanilton, had an identity and a following also, but were less inclined to hustle at the polls. It was not until after the Federalist 1088 to Jefferson in 1800 that Hamilton proposed the party organize local clubs, debate issues, and 
set up real party machinery.1 By the time of the presidential election of 1804, the Federalist party had become quite forlorn in its hope of steming the Jeffersonian tide. It did in fact receive only fourteen electoral votes in that contest. The extent of Federalist pessimism was expressed by the melancholy Fisher Ames of Massanhusetts when he wrote, "I fear Federalism will not only die, but all remembrance of it will be 10st." 2 However, the resumption of hostilities between England and France with the resultant seizure of neutral vessels and impressment of American seamen, leading to the subsequent policies of economic coercion of the Jefferson Administration, revived the hope of the despairing Federalists throughout the nation. Indeed, whereas by 1807 the Republicans had invaded the Faderalist stronghold of New England and captured the governorghip in every state except Connecticut, by the end of 1808 they had lost every one of them. ${ }^{3}$ One of the outstanding features of New England's history during the war that followed was the great opposition and obstruction posed by the powerful Federalist majority

IJames MacGregor Burns. The Deadlock of Democrac': Four Party Polftics in America TEnglewood CIIffs, N. J.: Prentice hall, Inc., 1963), PP. 27-31.

2Wilfred E. Binkley, American Political Parties, Their Natural Histony (New York: Alfred A. Knopf, 1958), P. 89. ${ }^{3}$ Ibid., pq. 88-91. 
to the national prosecution of the struggle. ${ }^{4}$ By the time of the war the Federaist Party in New England had completely changed from the principles of Washington and Hamilton, becoming practically anti-federalist to the point of discussing secession. Instead of following Washington's principle of avoiding foreign alliances, these Federalists openly supported the British cause, and in turn Great Britain showed its good will by opening its blockade of the east coast south to Hew London.5 Throughout 1814 the Federalist newgpapers in New England became more and more outspoken on the subject of dissolution of the Union, and on December 15 a Federalist convention met in Hartford to assert New Engiand's place in the Union and to propose amendments limiting the federal governments' power to declare war. ${ }^{6}$ Although the majority of Federalists in the north-east and Middle-Atlantic States believed that the Hartford Convention's proposals were sound, and that the delegates had a perfectly good right to meet and petition their federal government, 7 the political effects

4James Truslow Adams, New England in the Republic, 1776-1850 (Boston: Little, Brown and Company, 1927), P. 80.

5 Edward Channing, A Higtory of the United States (New York: The Macmillan Company, (936), IV, 226 .

${ }^{6}$ Adams, New England in the Republic, Pp. 285-99

7Shaw Livermore, The Twilight of Federalism; the Digintegration of the Federalist Party 1815-1830 (Princeton: Frinceton University Press, 1962), pp. 11-12; See also Theodore Dwight History of the Hartford Convention: With a Review of the Policy of the United States Government, which lad to the War of 1812 (We York: N. E J. White, 1833). 
were shortly to prove crushing.

When the news of Jackson's victory at New Orleans and of the Peace of Ghent reached Washington in January and February of 2815 , the commissioners from the Hartford Convention, who had cone to present their convention's resolutions, were forced to flee from the capital city as quickly as possible. With them they carried the ruin of the Federalist Party. The party was just strong enough to carry Messachusetts, Connecticut, and Delaware against Monroe in $1816--$ but that was the end. ${ }^{8}$ Indeed, "The Federalist party, which in twenty years had run the gamut from rabid nationalisn to Hew England sectionalism, accepted the defeat of Rufus $\mathrm{K}$ ing in 1816 as its death knell and quietly folded up as a national organization."9 Although $\hat{t}$ may be generaliy accepted that the federalist Party passed out of existence as a national organization soon after the llartiond Convention, that does not explain what happened to both the party and its members on the state and local levels. In describing the political conditions that existed in the state of Rhode Island from 1817 , the beginning of the Era of Good Feelings, to 1829 , the period might be conveniently divided into three segments: the years frors 1817 to 1820 , when there was a close balance between the Federalist and Republican Parties and when they continued political warfare;

${ }^{8}$ George Dargerfield, Era of Good Feelings (New York: Harcourt Brace 5 Co., 1952), P. 99.

${ }^{9}$ Leland D. Baldwin, Tha Stream of Araerican History (New York: American Book Company, 1952), I. 429. 
from 1820 to 1824 when the state's climate was more congenial to the dying Federalist Party than that in other states and where in 1822 the legislature was evenly divided but the Federalists were unable to elect their men to state-wide offices; and from 1825 to 1829 when a limited suffrage and an interest in manufacturing led to a successful amalgamation of many Federalists into the Adams Republican Party and the anti-Jackson ranks, while still another hard core of Federalists were drawn into the pro-Jackson party 10

It was New England's fear of andopposition to the War of 1812 that was instrumental in the growth of Federalist strength in Rhode Island prior to the war. In 1811 the Federalist candidate for governor, William Jones, was elected to office over James Fenner. In that year the Federalists also secured control of the previously Republican dominated General Assembly. Although the Federalist Jones was defeated for the governorship by Nehomiah $R$. Knight in 1817 by sixtyeight votes, it became even more apparent from the gubernatorial election returns of 1818 that the Federalists had lost the support in the state which they had gained during $120,131$.

10 Livermore, The Twilight of Federalism, pp. 82 , 
the war. In that year Elisha $R$. Potter, a man long associated with the Fedexilist Party on both the state and national Ievels, and the rest of the pedenalist Prox, the list of nominees for state offlee supported by that party, were defeated by Govexnov KnIght and the Republieans--Knight neceiving a majority of 616 votes over his opponent. Indeed, "as is true of most organlzatons, the Federallets, when they loot a cause to fight for, also 'lost the ability to win elections."12

Although Intense eampaighing was carried on by both sides, there was such a low regard for the once proud Federalist Party that its members even avoided using the term "Federiligt" when epeaking of thenseives, 12

It was the rise to power af the Rhode Island Federaligt Party in 1811 that brought Tristam Burges into prominenee. Born in Rochaster, Massachusetts, on February 26,1770 to Johu and Abigall Burges, he was the youngest of their three sons and one of efght ohildren. In his carly years, Tristan Burges received a spotty education in sehools near his home until he entered the Acadeny of a Doctor Wililams, at Wrenthan; Massachusetts in 1791 to tudy medieine when just over

\section{Kenrieth Thomas Langer, "Rlikha Reynolds Pottes, Sr.} Folitielan * " (unpublished Master" Thesis, The Univemefty of Rhode Island, Kingston, 1957), PP. 56-57; Charles P. Bennett, Manual with Rules and orders for the use of the General Assenbiy of tha State of Rhode IsIand, 1909 (Providence: E. L. Freeman Company, 1908). 10. 102.

12 langor. "EIisha R. Potter," pp. 56-57. 
twenty-one years of age. Two years latep, after leaving school in Massachus tts and ahort stint at teaching in his home town, he entered Rhode Island follege (Iater Brown Univergity) as a sophomore. After overeoming ing financial diflaulties with a timely win on a lottery tiaket, Burges turned to the study of public speaking and oratory under Dr. Jonathan kaxey, then President of the college. In belleslettres he deviedoped into a fine seholur, and at an eariy period became distinguished through his oratorical ability. Indeed, at the choice of his classmates he stayed to deliver the class valediatory address in 1796. After a short period as a school master in Fovidenew, Burges began reading law with Judge Barnes and was admitted to the Rhode Island Bar in 2799. He then settied down to practice law in his idopted state. 13 With his acceptance into the tate bax Buxges began an extensive and successful legal career. In Detober of 2799 he, along with Jeremiah Brown fowli, another prominent attornay, petitioned the General Assembly on behalf of two branches of the state militia. Because of declining membership the Governor's Independent Company of Volunteers and the Govemnor's Independent Company of light Infantry asked their agents, Burges and Howell, to petition so that

13

Henry L. Bowen. Memoir of Iristam Burges: With Selections from His Speeches and dcoasional Wmitings TProvidence: Marshall, Brown \& Co*v 1935 ), PP. $13-36$. 
they indght merge and have their names change to the United Independent Volunteers. While meeting in South Kingstow dusing the same month, the state house of Representatives approved the petition. That Burges had more thax just a passing interest in the state militia and was beconing active in Providence golety was deronstrated in 2805 by his elavation to the post of Comander in the same unit he had petitioned for six years earlier. 14

The star of the young lawyer was indeed rising ragldiy In his new heme. On May 22, 2801, he married Mary Axnold, the daughter of Welcome Arnold-ma proninent merohant of Frovidence. 15 having developed both fanliy and economic ties to the upper-elass marehante and manufacturers of Providenoe, it is not surprising that Burges also began to adopt their legal outlook and political vienpoint* In 2805 he signed a petition along wh th Samuel Amold, Patience Arnold, and Jogegh Martin (Burges Igned ds Martinte torney as well as on his own behalf) to gain a nulification of an adverse judghent given by the Supreme Court when it met in East Greenwioh in that year. Burges, moreover, defended the ohipeowner and mercantile interests of Providence agalnst the charges of seanan Whipple

${ }^{14}$ Petitions to the Rhode Island General Assembly (State Arehtyes: $\frac{\text { State House, Providence, khode Island) }, .32}{\text {. }}$. $57, V .36,0.89$.

25 James H. Arnold, Vital Recerde of Rhode Island

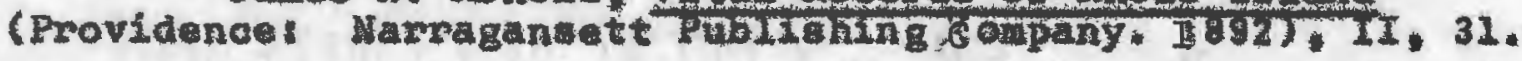


Andxew's widow thet her husband had been unjustly demoted from the rank of first-mate while on a voyage from Providence around Cape Horn to the South and Western United States. She contended that the owners had broken a contract and demanded restitution. Speaking for hiraself and his client, Burges charged that Whipple was relieved of his duties by the ship's captain for neglect and braaches of duty in violation of the interests of the owners. Upon presenting the deposition of a fellow crewman who supported the captain and the owners, the House of Representatives on October 31, 1806, upset the old decision and ordered a new trial be held.16 It is evident, therefore, that within six years after passing his bar exams Burges had become a successful defender of the vested interest group in his adopted city. This successful defense was to stand him in good stead with these groups in the future. As his law practice continued to grow to the point where there were "few important cases.. . in which he was not engaged," Tristan Burges also became interested in politics. This was about the time of Jefferson's Embargo, and Burges took the stand of the Rhode Island Federalist party during the excitement which followed. At public meetings held in Providence he was uswally present, and at several of 16 Petitions to the Rhode Island General Assembiy, $V$. $37, \mathrm{pp} \cdot 18,21$. 
then he made enthusiastic and successful addresses to fellow Federalists, 17 As the threat of war grew and it became popular in the state to oppose the policles of the Republiaan govermment in Washington, Tristam Burges grew politically. In the general statewide elections of 1811, when the Providence Gazette appealed to the people to back the Federalist William Jones and turn out the Incumbent "Fennertan Dynaty, "l8 the - lactorate reponded with a sweeping Fedaralist triungh. Anong those elected was Toletan Burges, who took his seat as a State Representative from Providence at the May, 181I, session of the General Assembly held In Newpert.19

While Burges was serving his term in the state General Assembly there were two for actions in which he took part. one Involving the establishnent of a new courthouse in Bristol and the other proposed revieion of the general election laws of the state. During the June session of $2811^{*}$ House speaker W11liam Hunter and Hepresentatîves Burges and Levi Totten were appolnted a comblttee to take into consideration the expedieney of ereoting a oourthouse in Bristol, to set up a plan, estimate the expenses, and determine if the state owned any land on which the structure could be bullt. 20

$6,1812$.

$$
\begin{aligned}
& \text { 17 Bowen, Mapolr of Tristan Burges, Pp. } 38,49 .
\end{aligned}
$$

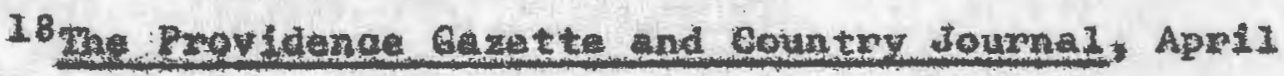

19 En mrossed Records of the State of Rhode Island (State Archtes! State House, Povidence, Rhode Isiand), V. 18, 104,

$$
20 \text { Ibidis p. } 220 .
$$


The comittee convened in Bristol in September of the same yedr au detaminea that the existing courthouse was in such a state of repair that its future use was inprecticable. It further decided that the old house whould be sold by the State and a new building be erected. Upon investigating, the comittee decijed the best location was in the comons of the town, on the same site occupied by the Bristol Academy; and after lengtiy negotiations with the town it was agread that Bristol would pay to move the aodany and that the state would then construct the courthouse. Fhis report, however, did not drab up any cost estimates on pland, and the successful completion of the plan was somewat delayed decause both Burges and Iunter failed to return to the House after the next elections. 21 Indeed it was not until 2816 that the matter was finally settled and construction begun. 22

The act involving change in the state election laws was much less "cut-and-didej" than the courthouse action, and shows much more cleariy the conservative outlook that Burges held at that tine. During the andy surumer of 1811 an act for regulating the manner of elocting the freamen of the state and the wethol of electing general state officers, which in assence was designaj to expand the state-wide surfrage, was

21

Reports to the General Assembly, State of Rhode Isiand, 1820-18I7 (State Archives! State house, Providence, Khode Island, No. 88.

${ }^{22}$ Engrossed Records of Rhode Is Iard, V. 29, PP. 423-25. 


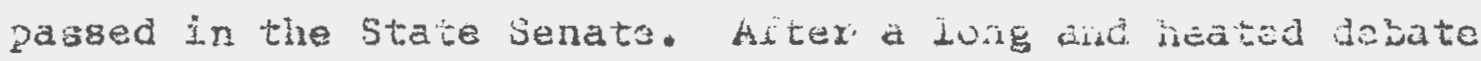
in tine House, Iristam burges was anong the trirty-aight who voted andint the wasure, ompared with thantyreight in favor. It is not known exactly who spoke ather for or against the bill, but Burges' oratorical ability anj his objections to a piece of legislation already accepted by the senate leads to speculation that he was one of the Representatives involved. Burges, moreover, was instrumental in having the suffrage bill defeated. At the same time, however, he voted in favor of exempting the astablishad vaters of the state from payment of a poll tax. Thus while Burges would lessen the restrictions on those who held the franchise and would support his own vested interests, he was unwilling to exterd the same benefits to others. 23 Because of his actions upholding the corservative Federaidst ideals oi governdent and his still growing anti-war spirit, Burges received a letter of commendation from the Federalist Governon Jones shortly before the state elections of 1812. Jores believed tint buriges was working for the public good and his actions placed him on higher grounci in the opinion of the Govemor. 24

In the elections of 1812 , the established electorate of Providence gave the Federalist Party a unanimous 541 to 0 1812.

23 ing Frovidence Gazette and Country Journel, June 22,

24 Governon William Jones to Iristam Burges, Providence, March 24, 1812, Misc. Mas., Box J, Jo. 728, Rhode Island Historiaal Society, Providence, R. I.. 
sweep of the 1ty; but Pster Grinnall replaced Burges, who although reelected, resigned hls seat in the General Assembly.25 The rason why Burges, flaing the cret of a uninous victory, should resig hil seat is not known, His one blographer ascribed his actions to the pressures of his law practice and the "pecullar state of partios at that time." but he does not explain what this "peculiar stete" was. 26

Perhaps a closer examination of Providence soclety and polities in 1812 w111 give a bettev explanation. During this perlod there were four hundred nechantes residing in Providance who were freemen of the town. They owned about half of the property in Providenee but were unrepresented in the legislature. On the other hand, for the treaty-flue lawyers of the city there were two representatives-mone being Tristam Burges: The property of these twenty-flve 1awyers, moveover. was worth about $\$ 150,000$ compared to $\$ 2,000,000$ for the property of the meehanics, 27 It would be an understatement to say that there wes considerable unrest among this group of unrepresented freemen. Indeed, Burges might have regigned not only because of the pressures of his law pratice, but alco to

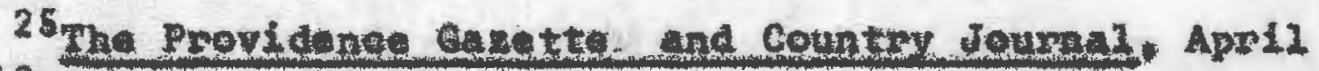 1.8, 1812 . \\ 28 Bowen, Memale of Trista Burges, D. 51. \\ ${ }^{27}$ rtapy Libero Renulii, "The Extent of Rhode Island's} Participation in the War of 1812 " (unpublished Master's Thesis, The University of Rhode Island, KIngston, 1988), p* 42 . 
preserve much of this practice and to hope for the support of this mechanic class in the future.

Although not in office but active in his law practice and civic affairs, the ex-legislator remalned prominent in the Federalist Party and continued to be leader in Providence society in the years that followed. Both Burges and his wife, Mary, were among the first pew-holders in the new First Congregational Society Church when it was established in October, 1816,28 Continuing as a leader, the lawyer was also selected by the town of Providenoe to serve on a comittee with Moses Brown, Samuel Eddy, George Jackson, and John Howland--all equaliy prominent citizeng--to draw up an historical and topographical description of the Great Storm of September 22 and 23,1815 . This was one of the most destructive storns that Providence had known up to that time, and the town wished to preserve a record of its happenings. When the report was finally completed, however, it bore mainly the signature of Mr. Brown. 29

\footnotetext{
28 "First Congregational Society Pew Holders," Rhode Island History, II (April, 1952), 47.

29 Moses Brown, "Official Record of the Great Gale of 1815." Publications of the Rhode Island Historical Society. New Series (Providence: The Standard Printing Company, 1894), II, 232-35; William R. Staples, Annals of the Town of Providence from its first Settlement, to the Organization of the City Government, in June, 1832 (Providence: Knowles and Vose, 1843 ), p. 379.
} 
Burges bease leading Federalist lawyer and leader of Providene soclety. It is not surprising therefore that the Federalist deminated Grand Committee (the State senate and House together) elevated Burges to the position of Chief Justice of the Rhode Island Suprame Court in May, 1817.30 Writing gone time after Burges" tenure on the benoh, one nember of the bar left the following impression of the. Rhode Island courts:

Little st interest can be found in print in regard to the character of the courts duping the Revolution and for fifty years afterwards. The judges continued to be annually eleoted and were mostly unleamed in the law. Courts so consisted were faulty of coureel but they seem nevertheless to have administered justiee with fair suecess. It is true that the tradition of the bar does not flatter then but tradition paints with a free brugh and delights in fantastic effects. The fact that ach able lawyers as William Ellery and David Howell were Hilling to serve in the higher coupt as assodate justices, and that James Burrill and Tristain Burges, at the zenith of their professional renoun, each filied the office of ohief justice

${ }^{30}$ Gordon F. Harrison, Lineal and Collateral Ancestors of Senator Theodore Francis Green Who Served in the American Congress (washington: n. p., 1955), p. 53; Bowen, Menolr of Tristam Burges, p. \$2, and Bennett, Rhode Island Mañul, pp. 240-41. AIthough Bowen and harrison date Burges term as Chief Justlo from Hay, 1815 , to $\mathrm{May}, 1816$; the Manual dates it from May, 1817, to May, 1828. In 1816 the FederaIIst Governor Jones was reelected by a 332 vote majority and the Federallet strength in the House was till double their opponents. It was not until Mr. Knight defeated Jones in 1818 by 616 votee and the Republicans gained eontrel of both Houses that they would be in a position to replace Burges as Chief Justice. Bowen also states that Mr. Burges was elected Chlef Justice upen the lection of Caief Justice James Burri12, Jr. to the Feéend senate in 2825. According to the Manual (p. 240) Danial Lyman was Chief Justice from May, 1812 to May. 1816, and Burrill from May, 1816 to May, 1817. The Manual also.pIaces the election of Burmill to the Senate in I817 (BP. $244-145)$, and not in 1815 as Bowen contends. It would seem, then, that Burges was Chief Justice from May, 1817 to May. 2818. 
for a year is pretty good proof that the court was held in high honor, for certainly it could not have tempted them by its emoluments. 31

Indeed the monetary rewards were not the main attraction to the office, for in 1789 the pay of the State Chief Justice was fixed at $\$ 500$ and that of the associate justices at $\$ 350$ per year. These rates prevalied until 1822, when they were lowered to 1250 anc $\$ 200$ respectively.32 Burges' tenure as chief justice proved quite short, however, for he remained in office only until the following May. When the Federalist Party foll out of power in both houses of the legisiature in 1828, the Repubiican opposition promptly peplaced the Federalist chief justice with one of their own, and exgovernor James Fennen succeeded Tristan Burges on the bench. 33 Upon his removal as chief fustice, Burges again returned to his law practice and a professorship of oratory and Belles Lettres at Brown University. 34 While engaged in these two pursuits, he also had time to seek support in establishing a boarding school for girls in Providence. He described Miss Burroughs and Miss Calder, the teachers, as highly accomplished and in every why qualified to run such a school, for they would teach English, reading, gramar,

31 Thomas Durfee, Gleanings from the Judicial History of Rhode Island (Providence! Sianey S. Rider, 1883), P. 8I.

${ }^{32}$ Ibid., p. 29.

${ }^{3}{ }^{3}$ Bennett, Rhode Is land Manual, DP. 240-41.

${ }^{34}$ Bowen, Memoir of Tristam Burges, PP. 51-52, 
mathematics, accounting, chronology and history, geography with the use of globes, belles lettres lessons and composition, omamental needle work, religion and morals, musio and danoing, and drawing and painting in oil, water colors, and crayons. Ail this for $\$ 2.50$ a week for board and $\$ 9.00$ per quarter for tuition, 35

As a lawyer Burges served the merchant and banufacturing elements of Providence society. In June, 1821, he petitioned the State General Assembly to set aside a judgment against his client, Providence manufacturer Thomas Sprague, because of damages allegedly caused by his mill-dam to property owned by one Caleb Hilliams of Cranston. Burges contended that the damages could not actually be attributed to Sprague and that the first trial had been a miscarriage of justice because his client had not been given an opportunity to prepare an adequate defenee. He also argued that the last decision was unjust because the jurors were townsmen of Cranston, friends of Williams and undoubtedly partial towards him. Aftar considering the matter until January, 1823 , the General Assembly finally accepted the arguments and ordered that a new trial be held.36 The arguments presented by Burges in this plea indeed pointed out the swing of many Federalists in New

35Tristar Burges to Janies Dewulfe, Frovidence, April 3, 1820, Shepley Papers, V. 16, No. 163, Rhode Island Historical Society, Frovidence, R. I.. $5.0, P=87$.

${ }^{36}$ Petitions to the Rhode Irland General Assembly, V. 
England from an interest in shipping to manufacturing. In 1805 Burges had defendea the commelal interests of Providence. Sixteen years later he was doing the same for the manufacturing element.

Although the Republican Party had gained the upper hand in the state with Nehemiah Knight's election as govemor in 1817 and 1818 , and retained it under Governors Gibbs and Fenner during the $1820^{\prime} \mathrm{s}, 37$ Tristam Burges was loath to give up the Federalist principles he had aequired. As late as 1824 his Fedenalist sympathies were still quite prominent. The visit of the Revolutionary War hero, Marquis de Lafayette, to Providence in August of that year was culminated by a banquet at wich Burges proposed a toast to the distinguished guest. After a day that was filled with a gala celebration, a parade through the streets of the city, and the official greeting at the State House by the Governor, Burges expressed the feelings of gratitude of Rhode Irland for the general's visit and of the nation for his great heIp in the Revolution. He ended his speech by saying:

- our eyes and hearts are turned to the same illustrious individuel whilo ve say

All hajil to

The companion of washington;

The follow soldier of Green and Hamilton;

The friend of Freadom:

The Citizen of Europe:

The gitest of the united states;

GENERAL LAFAYETTE. 38

37 Bennett, Rhode Island Manual, PP. 102-03.

38 The Providence Gazette, August 25,1824 . 
Indeed, Burges' linking the name of Habilton with those of Washington and Greene as a military haro without opposition or exitieism showed the strong Federalist sentinent of both Burges and Providence in general, "a sentiment that still lived, al though no man thea, when the memory of the Haptford Convention was fresh in the winds of the people, had the moral courage to dealare himself a Federaliat." 39

Thus it may be observed that alnost ten years after his party had collapsed on the national level and been driven out of power on the state level. Tristam Burges dontimued to espouse the Federalist outlook and Ldeals. But if Trigtam Burges could not call himself a Federalist, what then? In order to continue his career in polities he would have to do something about the etigna attaohed to the name "Pederallst." The Congressional elections of 1825 in Rhode Island presented hin with just such an opportunlty.

${ }^{39}$ Edwaw Field, od., State of Rhode Irland and Providence Plantations at the End of the Centurys A History CBoston! The Mason Publishing Company, 1902), I, 311-12. 
A NATIONAL REPUBLICAN TO CONGRESS

In 1824 a general swing of Federalists into both the Adams and the Jacksonian presidential camps made it impossible for Burges to remain true to his affiliation. Necessity, therefore, rather than any great change in his personal or political ideology caused Burges to gravitate towards the Republicans and to accept the 1825 congressional nomination of a convention of the old rederalist element in the Rhode Island Republican Party. This pro-Federalist convention was the result of a split in the Republican Party. At its nominating convention that year the incumbent Congressmen, Samuel Eddy and Job Durfee, were the leading contenders. Eddy was renominated unanimously, but Durfee was much less fortunate, being beaten by Dutee J. Pearce of Newport. The defeated Durfee then claimed that the convention did not truly represent the freemen of the state and announced himself as an independent candidate for re-election. The old Federal element, who had never been cordial in supporting the candidates ehosen by the Republicans, seized the opportunity presented by Durfee's bolt from the party and nominated Tristam Burges of Providence and William Hunter of Newport.1

$$
\text { lField, State of Rhode Island, p. } 313 .
$$


Indeed, by the sixth of August the IIst of candidates for the Nineteenth Congress included Samuel Eddy, Dutee J. Pearce, Tristam Burges, William Hunter, and Job Durfee--a2l alleging to be Republicans. 2

To compound the mix-up in party affiliation, The Providence Patriot announced its support of Dutee J. Pearce and William Hunter, one a Republican nomines, the other a Federalist, and neither an incumbent, as the only true Republicans and labeled Burges as the Federalist candidate. To prove their point, the Patriot's editors went back to Jefferson's election in 1800 and noted how only 56 Republians had been courageous enough to vote the Republican ticket in Providence. Moreover. they acoused Burges of having comented on this fact by saying, "then there are fifty-six r-m-g in Providence." They want even further to charge that if Burges supporters could find any deviation from his ultra-Federalist position in the last twenty-five years, then there would be at least one bright spot on his "political disk."3

Not content with just denouncing him as a Federalist, the Patriot continued to hammer away at she Providence lawyer. They demanded to know with what night he hoped to clain the support of the party with which he formerly acted when it was a known fact that he had not been set up by the entire organization but by only a few who were unsatiafied with the

\footnotetext{
The Providence Gazette, July 6-August 6, 1825 .

The Providenee Patriot, August $17,1825$.
} 
other candidates. The assertion that Tristam Burges was still a Federalist at heart was constantly reiterated and he was deolared to be the "federal" candidate,"

Despite the allegations of the opposition press about his political beliefs, the largest and most highly attended meeting of Republicans ever known in Providence, held at the Manufacturers' Hotel on Monday evening, August 15, adopted resolutions supporting Burges in preference to the inoumbent, Samuel Eddy. The Providenoe Republicans, moreover, said that Eddy had done nothing for Rhode Island during his six years In Congress; they opposed his vote in favor of the Missouri Compromise; and they accused him of having been a crawford supporter until the last minute. Burges, on the other hand, was termed a "warm and able advocate of John Q. Adams."5

The men behind these statements said they were forced to make them because the supporters of Eddy had led the people of the eity to believe that Burges had been nominated exclusively by the Federalist Party and would be supported only by 1 ts members. Indeed, the Republicans went on to stress that Burges should not be regarded as a Federalist Party candidate at aII.

Mr. Burges is not the candidate of any party-me stands

${ }^{4}$ Ibid. August 17,1825

5 The Providence Gazette, August $20,1825$. 
before the people on his own merits, as a generous and open competitor for one of the most responsible and dignified posts in their government. He has formed no seeret coalitions--he is propped by no Minority Caucushe relies on no political party.6

Sensing that there was atrong popular support for the ex-Chief Justice among many freemen of the state, the editors of the anti-Burges Providence Patriot circulated a handb111 "To the Fanmers of Rhode Island" on the ave of the election. Directed to the agricultural element of the state, the handbill denounced Burges as being a manufacturer, a friend to manufacturers, and controlled by the manufacturing intereats of Providence. The sad effects his lection would have on the farming interests in the state were enumerated, and $\mathrm{is}$ opponent, Samuel Eddy, was declared to be the true friend of the farmers. 7

This last ditch effort to stop the Providence attorney and swing the election to the incumbent proved to be a fallure. On election day, August 30,5,556 votes were cast. A majority was needed for election. Tristam Burges, receiving 2,932, neariy 300 more than his nearest rival, was the only candidate lected. A run-off election was held the following November to determine who would accompany hin to Washington in December, and Dutee J. Pearce was chosen as the state's second representative. 8

${ }^{6}$ The Rhode Island American, August 19, 1825 .

7 Ibid. August $30,1825$.

${ }^{8}$ Bennett, Rhode Is2and Manual, p. 266. 
In the Wineteenth Congress, Which nonvened in Dacember of that year, were a number of notable figures with whom the newly elected representative from Rhode Island would be associating. Massachusetts boasted of having both the oratorical ability of Daniel Webster and the leamed and prom fessorial talents of Edward Everett; Louisiana olained the learned jurist Edward Livingston, who had done so much to araft a penal code and a code of prison discipline in that state; and from Pennsylvania there was John Sergeant, one of the most learned and accomplished constitutional lawyers of his day.9

Hardly had Burges situated himself in the nation's capital when he began receiving wall from his constituents. One Republican reminded him that the welfare of the country would be best promoted if he supported the measures of the administration, worked for aquitable tratment of the Indians, and acted according to his own prineiples on any question regarding slavery--remembering of course the sentiments of his friends in Rhode Island. 10

A few weeks after Congress assembled, bill to enlarge the Supreme Court was introduced into the House of Representatives. The main feature of this administration measure

9 Bowen, Memoir of Tristam Burges, p. 53.

10 William Almy to Tristam Burges, Cranstor, December 28, 1825. Misc. Mss., Box A, AI ER, Rhode IsIand HIstorical Society. 
was the creation in the new states of the Mississippi Valley of four new judicial circuits designed to raise the total number of eircuits in the nation to ten. District judges would then maintain jurisdiction in all of these areas except western New York, western Pennsylvania, and western Vinginia-where the district judges of the ten areas were to perform lesser circuit court duties on rotating basis. These ten new circuit areas were then to be combined into an enlarged national Supreme Coupt of ten justices. As soon as the bill was introduced onto the House floor, Representative Charles F. Mercer of Virginia offered a counter resolution to recommit the entire subject to the Judiciary Committee for further study: ${ }^{12}$ It was in support of Mercer's resolution and in opposition to the bill itself that Burges chose to delfver his first address as a Federal Representative: Speaking against the measure on January 23,1826 , he listed the evils that many felt the new bill would remedy. After noting that it would equalize judicial administration, judicial representation, and knowledge of state laws, he then proceeded to speak in favor of the motion to reoomit and to debunk the arguments of the bill's proponents.

Burges argued that the bill, because of its exclusion of over one million people in western Pennsylvania, Virginia, and New York, did not even make an attempt to equalize judicial

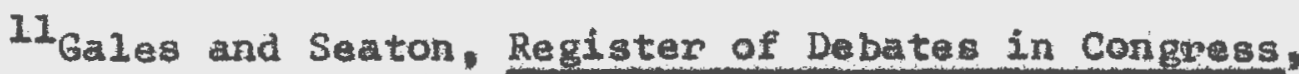
I9th Cong., Ist Segs., II, 1082. 
administration. Instead of giving equal judicial representation, he stressed that the new bill would make the court an agent of sectional and partisan politics. Such a measure, Burges felt, would bring the "gxeat doctrine of electioneering" to the court and allow it to work either for or against particular candidates. On this point Burges disagreed with his northern neighbor, Daniel Webster of Massachusetts, calling his idea of limiting the number of Supreme Ceurt Justices, by practical convenience a political heterodoxy. The Rhode Islander argued also that the new bill could not bring a greater equalization of jualial knowledge than already existed. The only way a judge could learn the laws was through reading and study--and yo law could guarantee this. 12

Burges, moreover, saw a great danger embodied in the proposed legislation. He feared that the idea of having ten Supreme Court judges for ten circuits would lead to demands for a new judge with each new circuit. Although the advocates of the measure said there should be no concern on this matter for another twenty to fifty years, the Rhode Islander saw at least ten more new states being admitted to the union within twenty years. 13

On January 24 , the day after Burges' speech, the resolution was voted upon and defeated without further debate.

${ }^{12}$ Register of Debatas in Congress. 19 th Cong., Ist Sess., II. $1086-095$. 
Not content to let the freshadn Representative's speech lie in defeat, however, the Chairman of the Judiciary Committee attacked Burges and denounced hir as a supporter of the old midnight judiciary established to bolster a dying administration of an earlier period, ${ }^{1.4}$ thus rasing the spectre of Federaliam that had foliowed Burges from Rhode Island and from which he was struggling desperately to disassociate himself. The defeat of Mercer's resolutinn in January proved to be only a teraporary setback, however. When the entire judiciary bill came up for its final vote in May, Burges again expressed his disapproval. This time amon the majority ( 99 to 89 ), he voted against the expansion of the Supreme Court and helped cause its defeat. 15

Despite his opposition to an administration measure supported by Webster and designed to give the President a chance to appoint at least two new justices,16 Burges could not bring himseif to say anything against the Adams administration or John Quincy Adams personally. He said, moreover, that if the President continued throughout his first term as the same profound scholar, enlightened statesman, ardent patriot, and exemplary Christian, there would be no doubt

14 Ibid., PP. 1086-2000.

15 Register of Debates in Congress, 19th Cong*, 1st Sess., II, $2647-\overline{648 .}$

I6 Samuel Flagg Bemis, John Quincy Adams and the Union (New York: Alfred A. Knopf, 1956), P. 75 . 
of his re-election in 1828.17 Burges was playing politics. Elected to Congress as a National Republican and a supporter of Adams, he found himself unable to support the expansion of the conservative Federalist dominated supreme court; but neither could he allow himself to be called an opponent of tire adainistration. Using the kindest words possible, the Khode Islander made a valiant effort to both oppose and support Adams at the same time.

In his first speech Burges also showed his feeling toward the doctrine of territorial expansion and the belief that the Ainerican people had a pre-emptive right to the North American Contivent.

will not new States arise? Already, sir, you have three new territories. Florida is spreading her population down to the very margin of her watars, and enriching her cultivation from 'the cane-bearing isles of the West.' Arkansaw [sic] is looking up the channel of her long rivers, towards the Mountains of Mexico, and will soon become ricr, populous, and highly cultivated. The tide of migration is setting up the grand canal towards Michigan; and that peninsula will, in a short period; be located and peopled from Lake to Lake. These three, sir, in less than five years with due courtesy and fair cause for admission, will knock at your door, and propose to sit down in the ramily oircle of poitical Union. This is not all, sir. Population is travelling up the latitude across your northem territory, towards the great Caspian of our continent; and when they shall have heard of your ships on the waters of the Oregon, and of your colonies along the rich valleys of that river *. . these peopie will, sir, with the rapidity of a deep sea-lead thrown from the chains of a seventy-four, plunge down the iongitude to meet and mingle with their

\footnotetext{
II, 1083 .

17 gegister of Debates in Congress, 19th Cong., lst Sess.,
} 
countrymen on the waters of the Pacifj.c.18

Indeed in an expansionist mood, Burges ended his speech with the American Eagle winnowing the breezes of the Atlantic with one wing and hovering over the Facific with the other, "until the colossal power of the Republic, standing on the lofty mountafns of this continent, shall, with one hand, extend the olive branch to the peaceful nations of the earth, and with the other wave the sword of justice oven the satisfied and tranquil citizens of these widely extended regions."19 Thus far had he moved from the parochitl feelings he had voiced just bafore the War of 1812 !

The first real conflict to develop between the purties energing under the Adans adminfstration was over the degree to which the country mould participate in the Panama congress. From the beginning Henry Clay was the champion in the Senate of the new Latin Anerican Republics, and he desirad to see the United States lead in a movement for cooperation among the countries of the New World. The President was also interested, but for other reasons. Adams feared the designs of George Canning, the British foreign minister, and of Generai simon Bolivar, the pronater of the ali-American Congress. By hid ow hand Adans made possible the strife that

$$
\begin{aligned}
& 18^{\text {Ibid., }} \text { pp * } 1092-093 . \\
& 19_{\text {Ibid., p. } 1095 .}
\end{aligned}
$$


resulted in both houses. We would not act until the Senate confirmed his two appontess and the House voted the necessary Iunds. This was an action contrary to president'g belief that foreign policy was an activity on wish the executive alone should decida, 20

In the douse the inajority of the debate centered around the resolution of Congressman Mcind of Dalaware. On April 4, 1820, in an atteipt to tie up the Eoreign kelations Connittee' a resolution that the House appopriate the necessary money as quickly as possible, and to discredit the administration forces, Molane fesolvad that the delegates being sent to Panana go in a dipionatic chanactar only ani de forbidden to nake any treaties or to "discuss, considen, consult, upon any proposition on alijance, offensive or cafensive, between this country and any of the South Arienican Govemrants.n21 Inmediately the friends of the President, led by liebster and with Burges in full support, ergued that such ar. anendrent had no grounds under the constitution and might inded be construed as direct instructinfrom the House to the ministers selacted for the mission. Backing dom a little, the opposition forces, now led by James suchaman of Donngylvania, the next day offened andmendment to Hchane's mendment that the House

20 William 0 . Lynch, Fifty Years of Party warfare, $1789-$ 1837 (Indianapolis, Indiana Tite Bobos-Merrill Company, 1931), pp. $334-35$.

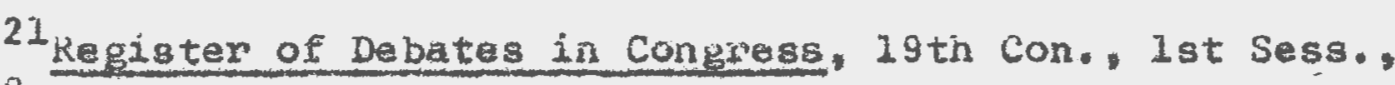


would only "deem it inexpedient" for the ministers to enter into any alliances.22 This took much of the element of force and unconstitutionality out, and the two amendments were ordered to be printed.

Although Burges delivened no formal address on the Panama missinn, his disgust at the delaying tactics of the opposition and his own opposition to Mclane's ideas were made evident in a letter to his son:

The eternal Panama Mission is still compoding ayay the presous [sic] moments of our remaining time. The question seens not now so much whether ife shall mak? the appropriation as whether we shall annex it to MoLane's condition. Disgraceful as it would be to the House I fear this resolution in some shape or other will pass. Burges felt that if the resolution must pass, it should be separated from the appropriations bill. As he saw it, the great object involved was for the United States to gain as many conmercial treatias with South America as possible. 23

What Burges hoped would happen regarding the amendment eventually took place. Although the House initially voted $9 y$ to 95 to accept the resolution, with Burges in the negative, it turned around anj on April 21 decidedly defeated the original resolution of the Foreign Relations Committee as amended by Mcluare. The vote was 54 yeas to 143 nays, with Burges and his colleague voting for the defeat. It must be

$$
22 \text { Ibja., p. } 2029 .
$$

23 Iristan Burges to his son, Washington, April 9, 1826. Peck Mss., Box XII, No. 58, Rhode Island Historical Society. 
pointed out, however, that these motions were kept separate from the appropriations bill, which was approved the next aftemoon 143 to 60 , with Burges in the majority. 24

The major portion of Burges' time for the remainder of the Nineteenth Congress, with time out for a battle with chronic asthma and family bereavement by the death of a aaughter, was spent in fighting to obtain passage of a relief bill for surviving officers of the Revolution, and a bill to raise the minimum duty on wools and woolen goods imported into the country. As the bill for Revolutionary officers was originally reported out of committee, the provisions for amounts of money were left blank--to be filled in at the discretion of Congress. 25 It was then that a three-ring circus began. On April 26, 1826 on the motion of the Pensions Comittea Chairman, Joseph Hemphill of Pennsylvania, the House provided the surviving officers ith $\$ 1,000,000$. The House then voted $\$ 1,200,000$ for the enlisted soldiers and cut the length of service necessary for qualification from nine months to three. As a member of the committee, Burges got into the act May I Sensing possible political advantages at home he upped the ante for surviving officers from $\$ 1,000,000$ to

${ }^{24}$ Register of Debates in Congress, 19th Cong. 18t Sess., II, $2456-457,2490,2514$. It should be noted that of the two delegates selected to GO, John C. Anderson of Kentuoky died enroute and John $S_{a r g e n t}$ of Pennsylvania arrived too late. Little of value was accomplished at the congress.

$$
25 \text { Ibid., p. } 2520 .
$$


$\$ 1,200,000$ (pissed 70 to 47 ),26

The opposition was not lax in establishing a roadblock, however. As soon as Burges' amendment had been approved Congressman Benjamin Estill of Virginia whs on his feet denouncing the bill for its haphazard construction and lack of documentation. In a surprise aet he moved that the bill be recomatted, and despite the urgings of Burges and $\mathrm{his}$ fellow Rhode Islander, Dutee J. Pearce, the Estill forces carried the day. By the slim vote of 90 to 85 the House voted on May 2 for a recommittal--thus killing the bill for the remainder of the sassion. 27

When the Nineteenth Congress reconvened for its second session in Decamber, Burges again took up the fight for a pension bill. Now sarving as Pensions Comittee Chairman, the khode Islander reported the bill out of comnittee for the second time on January 4, 1827 and had it placed before the Committee of the Whole House for consideration. He then suggested two separate bills, one for officers and one for all enlisted men, excluding the state militias. He moved that everything after the enacting clause of the old bill be struck out and the two new bills be inserted. Largely because of objections to the split nature of the bills and the exelusion

$$
\begin{aligned}
& { }^{26} \text { Ibld. }, p p=2532,2558,2573,2589 . \\
& 27_{\text {Ibid. }} \text { pp. } 2592-593 .
\end{aligned}
$$


of the militia, however, Burges' motion was defeated, 95 to 53.28 Burges then moved to insert an amendment combining his two bills into a single form including both officers and enlisted men-but still excluding the militia. In ciefense of his position he argued that the House had no constitutional right to include the militid and that if anything ware granted to them it would have to go through the state governnents. Although the comrittee of the Whole accepted the bill as arnended and reported it to the floor for debate, 29 the stand taken by Burges is strongly resilniscent of his advacacy of state control of the militia during the war of 1812 and of his service as an officer in the shode Island organization.

Once again the opposition pounced on the bill and it became bogged down in partisan polities and parliamentary maneuvers. Finally, on January 28 , it was sent back to the Committee of the Whole by the narrow maxgin of four votes, 97 to 93. It was considered briefly on January 22, but before any votes were taken the comittee rose and formed itself into the House of Representatives, 30 leaving the pensions bill of the Nineteenth Congress dead. The bill continued to be

28 Register of Debates in Congress, 19th Cong., 2nd Sess. III, $602-34$.

$$
\begin{aligned}
& 29 \text { Ibid., PP. 632-34. } \\
& 30 \text { Ibia., PP. } 732,777-78 .
\end{aligned}
$$


a political football for another year, however, and was Hinally passed on May 13, 1828 with 1ittlo opposition.31 While the debate over the pensions bill was raging, another measure that was to prove fan more important to both the Rhode Igland Congressman and his constituents was brought forward. Because the tarift of 1824 had not given the Anerican woolen manufacturers the protection they expected and since English goods undex-sold American goods in the domestic Inarket, the degressed raanufacturers sought relief Fron Congress. One such depressed entrepreneur was Zachariah Allen, Providence manufacturer whose woolen broadeloth mill in hortin Providence was capitalized at $\$ 94,000$ - une of the largest in the state. 32 Tristam Burges and Zachariah Allen had both married daughters of welcome Arnola.

As soon at Congress wassembled in December, 1826 , Burges mote to his brother-in-law asking for data, statements, and calcalations that could be used in establishing a higher tariff on imported woolens. ide also raquested copies of memorials written by Providenca manufacturers to hand out to the meinbers of Congress whom he felt could make good use of them. Although he foresaw a fight between providence

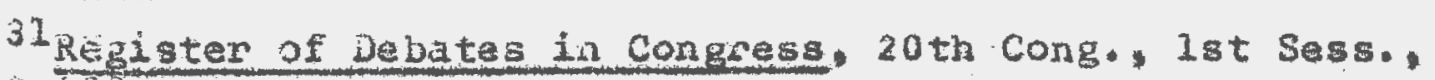
IV, $2596-662$.

32 Pater J. Coleman, The Transformation of Rhode Island, 1780-1860 (Frovidence: Brown University Press, 1963), P. 98. 
manufacturers and New York merchants, he was sure Providence could bring pore pressura to bear on washington than could New York. The Congressman also informed nis relative that "You may be assured of tay best gervices in favour [sio] of the Memorials [asking for higher duties] both on acct. of my friencis who are interested in its success $\varepsilon$ because I am persuzded that the interests of the country requires it." ${ }^{33}$ Burges was in on the political maneuverings behind the woolens bill from the very start. After conferwing with Congressman Rolitin $C$. Mallary of Vermont, the bill's sponson, it was decided that the measure would have the best chance of passage if it came up under the mask of a sill to prevent frauds on the reverue. It was also fis idea that the woolen anufacturers have an agent in washington to protect their interests. Since he was convinced that no wan in the country knew as much on the subject of woolen duties as his brother-in-law, 3urges was quick to suggest that zachariah come south. 34 Busines 3 pressures, however, were to prevent this from developing.

On January 17,1827 , the House took up Mallany's bill

${ }^{33}$ Tristan Burges to Zachariah Allen, Washington, December 5. 1826. Pack Mss., Box XII, No. ÔI, Rhode Island Historlaal Society.

34 Ibid., December 11, 1826. No. 62. 
"for the alteration of acts imposing atutes on inports." In the bill, the ad valorem rates on woolens were not touched. but four miniaums were to be eatablished. All wolens whose aeturl value at the place of importation was 40 cents or leas per square yard were to be valued at 40 oents; tween 40 cents and $\$ 2.50$ at $\$ 2.50 ;$ and between $\$ 2.50$ and $\$ 4.00$ at $\$ 4.00$. The duty on raw wool was to be advanced to 35 per cent after June 1, 1828 , and to 40 per cent year later. As a final provition, the duty on raw wool coating between ten and 40 cente per pound was to be set at the higher figure. 35 The day after the bill oane up, Buchanan of Penneylvania

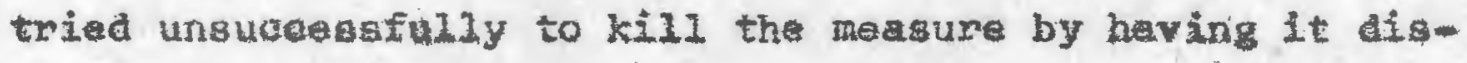
oharged from the coranittee of the whole, there it was baing considered, with the growed intention of laylng it on the table: Burges was quide to rige in opposition. To tablo the neagure, he abgued, wotd be to k112 It for the rest of the epssion while the woolen manufacturers needed rellef as soon as pousibie. It would be, he aldimed, unjust for congress to delay six months walting for information that could be obtakined fn a few weaks. Largely because of the se arguments the bill was not removed from comnitte as Buchanan had

${ }^{35}$ Register of Debates in Congress. 18th Cong. 2nd Sege. III. 740-46, Crrin Lesile LIII0t, The Tariff Controversy in the United States, 1789-1833. With A Sunmary of the Feriod berore the hicotion of che Constitution (Palo Alto California: Stanford univereity Press, 1392), pp. 238-39. 
hojed. 36

After the Conmittee of the Whole had considered the bill and itbelf discharged it on to the House floor for debate, Burges remained in the thick of hattle. On January 22 he again pleaded that the bill not be delayed to sea if other sectors of the economy, especialiy the Net York nerchants, were in the same depressed conditions on would be if the bill passed. If thoy were he reasonad, they would have petitioned for relief or in opposition to the bill as was the nomai procedure. It was also emphasized that the main object of the bill was to give the manuracturers of woolen goods the saie protection they shoulu dava raceived unden the tariff of 1824 , Dut hadn't., 37

Tensions ran high in the House on February 7 when it refused by three votes $(104$ to 101$)$ to allow the apposjtion to recomat the bill and kili it by delay. On the same day Burges again successîtully defended New England woolen fanufacturers agafinst wore attacks by Buchanan, who still opposed the measure as designed to aid Wew England at the expense of his own state. Three days later the opposition again went down to defeat when their movement to table the bili indefinitely failed, 84 to 109, with Burges and his colleague in the IIT, $747-49$ 37 I pia., D. 782 . 
majority. Sensing a preponderance in voting strength, the advocates of protectiun then moved to consider the bill itself, and it passed by 106 to 35 with the triumphant Burges voting in favor. All these successes proved to be in vain, however. Eighteen days later the Senate voted by a one vote margin, 21 to $20-$-tha deciding vote cast by Vice-President John $C$. Calnoun, to table the woolens bill and thus effectively kilied it. 38

The defeat of the Woolens $B i 11$ of 1826 and 1827 was not the end of the struggle to establish a more protective tariff, however. Indeed, in many respects it was only the beginning. Events that were to take place over the suramer of 1827 and before the convening of the Twentieth congress gave the controversy a new intensity and a new meaning-a meaning that Congress, once assembled, could act upon. 


\section{III}

LATER AUAHS YEARS: THE TARIET OF 1828

During the sumer of 1827 there were two distinct events that prepared Rhode Island for the stormy session of Congress that was to follow. The first centered around the electian of state pepnesentatives to the Twentieth Congress and the other around the demands made by a convention at Harrisburg, Pennsylvania, regarding the tariff.

The political atmosphere in the Union's smallest state was noticeably calm during the summer of 1827 . Indeed, toward the end of June one major newspaper stated that while a few people in the state desired sone sort of political change, there was, "happily," no agitation by either the pro- or anti-Adams factions. 1 It was not until nearly the end of the same nonth that any candidates were nominated. On Tuesday, June 25 , a meeting of people friendly to the administration" was held at the State House in Hewport, and Tristar Burges and Dutee J. Pearce ware easily menominated.2 It is interesting to note, however, that no party name was mentioned--the candidates were simply described as being in

1. Rhe Rhode Is Iand Anerican añ Providence Sazette,

June 26,1827 .

Ibid., June 29,1827 . 
sympathy with Adame.

At a convention of "regular" Republicans, held in the same place the following evering, there was pepresentation Fros why tibitied wi the state's thinty-one tows-and even less excitement over the nomination of candidates. In the course of the digcussion over the possibility of endorsing the nomination of Burges and Pearce, Nathan B. Sprague of Mithfield objected, saying it woulc be far better for the true Republican Convention to dissolve without making any mominations. It was his contention, moreover, that while Pearce was generally accotable to all Republicans in the state, his running-mate was not. sprague brought up the old issue that Burges had long bean associated with the Federalist Party and that "there would be ame objections in the minds of oid Repubicans to nominate that Gantleman in a RepubIican convention." After a few short speeches on the subject, the convention finally resolved that because Burges and Pearce had done their job sell enough it would be inexpedient to oppose then, but neither did it officially support them. ${ }^{3}$ Thus while Burges was no longer opposed by many of the state"s Repubilicane, to a significant minority he was still associated with the Eederalist Party and would be openly opposed.

Once the nowinations were over, however, the campaigning settled down and was exceptionally quiet. The two incumbents 
were elected without opposition. 4 so lop-sided was the balloting in August, that of the 283 votes cast in Providence Pearce had all except three and Barges all but four. 5

The protective system was also an area of prime concern during the sumner of 1827. After the defeat of the Wooleng Bill in 1827 many Rhode Islanderg st1ll had high hopes of raising the tariff walls as soon as possible. The state sent four delegates to the Karpisbuxg Convention for the Encouragement and Support of Domatio Induatry. The convention, attended by almost all of the Northeastern and Central states (including Kantucky, Ohio, and Virginia) resolved that while it would advocate the ${ }^{2}$ ising of protective barriers on all the industries represented, the interests of the wool growers and manufacturers, due to their bacly depressed conditions, would be the main concom. 6

AIthough the eupporters of Andrew Jackson alleged that the convention was little more than demonstration by the administration forces to use the protective movement for political ends, 7 it may be seen that 1 t was not really a

4 Charles Carroll, Rhode Ialand, Three Centuries of Democracy (Hew York: Lewis Historieal Pablighing Company, Inc., 1832), p. 568 .

\section{The Rhode Igland Anerlean and Providence Cazette, August 31 , 1827 .}

6 procegdings of tha General Convention of Agrioulturists, and Manufacturers, and Others Friendly to the Encouragement and support of the Domestic Industry of the United States (no place: no pub., 1827), Pp. $1-3,10$, Tariff Pamphlets, I, University of Rhode Island.

7F. W. Taussig, The Tariff History of the United States (New York: 6. P. Putnan's Sons, 1901), P. 84. 
gathering of either Adams on Jackson men--but of men from both sides who were andently commited to a highen tariff. 8 A higher tamiff was what the delegates at Harrisburg sought. The proposition regarding wool and woolens, so important to Rhode Island, asked for many features strikingly like the bill defeated in Congress only a few months earlier. A duty of 20 cents a pound an al1 wool costing 8 cents a pound was asked for-to be increased by $21 / 2$ cents annualy until 50 cente was reached. On most imported woolen goods a 40 percent auty was asked, to be increased to 45 percent after the first year and to 50 percent after the second. Four minimum duties were also suggested: goods valued at less than 50 cents per square yard were to be taken at 50 cents, then $\$ 2.50$, the third at $\$ 4.00$, and the fourth at $\$ 6.00$, These clauses were frankly intended to place the duty on wool at a jrohibitive rate, and it was openly avowed that the minimum duty idea was designed to produce an open market in certain types of goods for the American manufacturans. 9

When the Twentieth Congress convened in December, I827. Tristan Burges was present but did not take an active part in the debates for over a month. In september his youngest daughter, age 24, had died; and the following month his eldest

$$
\begin{aligned}
& \text { 8ynoh, Fifty years ct Parcy darsare, } \vec{p} .340 . \\
& { }_{\text {Edwara Stanwood, Anerican Taniff Controversies in the }}
\end{aligned}
$$
Nineteenth Ćentury (Boston: Houghton, Mitilin and Company, 1903), I, 266. 
daughter, age 23, followed her younger sister. Bowed down with family grief and confined to his lodgings with recurrent asthma, there was little he could do in the first weeks of the session. 10

Despite his inability to take part in the early actions of Congress, the Rhode Islander continued to inform himself on the feelings and desires of his constituents. Late in December he received memorials from the Providence manufacturers to distribute concerning the tariff. He was also reminded to call the attention of the members of the House to the desires of the Harriaburg Convention. His brother-in-law informed him of a feeling of disillusionment that had set in among many people of New England because President Adams had failed to mention eituer the American sygtem or internal improvements in his message in Congress. New England had expected zealous support of a higher tariff from the adrinistration, but as it was, they feared Adams had jeopardized his popularity by not mentioning a subject that had become disagreable to certain elements in the South.11

The ideas on the tariff drawn up by the Harrisbure Convention were not destined to appear before Congress, however.

10 Bowen, Memoir of Tristan Burges, pp. 57-58; the New York Daily imes, October 15, 1853.

11 Zachariah Allen to Tristan Burges, Providence, December,

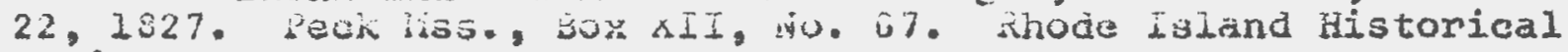
Society. 
The partisan feelings that had developed between the Adans and Jackson men since the election of 1824 prevented $i t$. Through a combination of the pro-Jackson Southerners and Pennsylvania Democrats, the anti-tariff forces were able to place ane of their own men, Andrew Stevenson, in the Speaker's chair. Stevenson then proceeded to staok the Comittee on Manufactures, which would consider any tariff bill, with a decidedly anti-protectionist majority while leaving Mallary of Vermont on as Chairman. The first indication of the opposition's plan came on the last day of 1827 when the committee, over Chaiman Mallary's proteet, voted to send for persons and papers to examine the need for a change in tariff legislation. Although protectionists were startled and united against what they interpreted as a delaying action, it was sustained by the Southern coalition 102 to 88.12 The second move of the anti-tariff group was even bolder. The new bill was prepared which, while it seriously modified the woolens schedule, contained other clauses and rates designed to make it obnoxious to most protectionists.

The new bill would raise the duty on hemp from $\$ 35$ to $\$ 45$ per ton, on molasses from 5 to $71 / 2$ cents a gallon with no drawbacks for rum manufacturers, on pig-iron from 56 to $621 / 2$ cents per hundredweight, on hamnered bar-iron

12Elliott, The Tariff Controversy, pp. 241-42. 
46.

from $\$ 30$ to $\$ 37$ per ton.13 The most controversial feature of the new bill was the proposed alteration of the wool and woolen duties. Under the tariff of 1824 the duty had been fixed at 30 percent. This was now to be changed to a mixed specific and ad yalorem duty. Wool, moreaver, was to pay seven cents a pound duty plus 40 percent in 1828,45 pereent in 1829, and 50 pereent thereafter. 14 The south hoped to make this bill so unacceptable to the Adams protectionists of the Northeast that they would be foroed to defeat it; while the Jackson men of the North, knowing the measure would be defeated, could support it and tern themselves as the advocates of mound protectionism.

In preparation for the heated debate that he knew would come and in which he eamestly desired to take part, Burges began to fortify, himself wth information from his manufacturing connection in Providence. On January 23, Zachariah Allen sent estimates of both the fixed and circulating capital in his woolen business, and described how this capital was constartly fluctuating because of the sexsons and sales. Burges was informed, moreover, that during the last half of $1827 \mathrm{hig}$ brother-in-law had been forced to hold this stock rather than sell it at prices

${ }^{13}$ Percey Ashley, Modern Tariff History (New York: E. P. Dutton and Company, 1911), pP. 193-94. 14 Tausaig. The Taniff History, pp. 89-9I. 
greatly depressed by English competition.15 In another appeal to his congressman-relative, Allen told how he had lost over $\$ 20,000$ since starting his business in 1822 and how he feared being forced to abandon his effort unless some relief was soon in coming. 16

Burges was also informed that the new tariff had excited a great deal of interest in his home state. Indeed, there was a feeling among many in Providence who had originally supported the Harrisburg resolutions that the reported Congressional plan of duties on hemp. molasses, and woolens shauld be opposed. It was felt that the new duty on wools and woolens would utterly destroy the state's manufacturers of coarse woolens and be of little benefit to the makers of finer grade products because the increase in duty on imported raw wool came far too soon and would not allow the time needed for the domestic flocks of sheep to increase to the point where they could supply domestic consumption. Some consideration, it was asserted, should be provided for in the reantime. 17

It was not just the wools and woolens provisions that were of major concern to Rhode Island and her representatives. Reflecting the new desire to establish ties between New England and the West, a feeling existed that if the duty on molasses was opposed by the East it would have a detrimental

15 Zachariah Allen to Tristam Burges, Providence, January 23, 1828. Peck Mss., Box XIII, No. 1 .

${ }^{16}$ Ibid. No. 2. January $24,1828$.

17Ibid., No. 3. February 11.1828. 
effect on the minds of the agriculturalists in the Middle and Western states.18 The men who believed this, moreover, represented a growing number of Northeastem manufacturers who saw the benefits that could be derived from economic and political links with the West. Allen informed Burges that if his colleague, Dutee J. Pearce, were so blind as to vote against the new duties on molasses merely to please a few distillers and importers in his home town of Newport, it would surely bring about his political death. 19

As Zachariah Allen's letters to his brother-in-law would indicate, there was a great deal of disagreement in various sections of the state on the merits of the proposed legislation. In the cities of Warren and Bristol many people saw the proposed increase of duty on molasses and the abolition of any cutback for rum distillers as a deliberate plot to bring the total destruction of the distilling industry on New England. It was generally felt that the proposed piece of legislation would return the towns to ad days of the Embargo and NonIntercourse. The distillers argued that it was up to the government to extend the same protection to the makers of rum as to any other industry, even if it meant a downward tariff revision. They appealed to their representatives to act

$$
\begin{aligned}
& { }^{18} \text { Ibid.. } \\
& { }^{19} \text { Ibid., Fevruary } 13,1828 . \text { No. } 4 .
\end{aligned}
$$


accordingly, In the "twue principles of a judiclous tariff." 20 The shipping interests of Providence were also hotly opposed to any mpward revision of the tariff. Dearying the fact that their commerce had fallen from 15,490 tons in 1821 to only 13,125 in 1828 , the merchants argued that one segment of the economy should not be protected at the expense of another. It was their belief, moreover, that if the domestie manufacturers followed more rigid econonies and paid closer attention to improvements, they would not need to apply to Congress for more protection at every session. 21

Aligned with the state's poolen manufacturers, and In direet opposition to the distilleps and shippers, were the makers of cotton goods--especlally the finer grade products. Arguing for a high tariff on iaported fine cotton goods, this group feared that many among its numberg would either be forced to revert to making poorer guallty goods or go out of business antixely if they were not ganted an increased degree of protection. 22

20 Memorial of the Citizens of the Town of Warren, In the State of Rhode Island, Against an Increase of Duty on Molasses Imported, February 25,1828 (Washington: Gales and seaton, 1828) PP: 3-4; Remorial of the citizens of Bristol, In the State of Rhode Island, Against in Increase on Certinin Imported Manufactures, March 3,1828 Washington: Gales and Seaton, 1928), PP. 3-4.

21 Representation of Sundry Citizens of Providence, In the State of Rhode Island, Upon the Subject of an Increased Duty of Certain Imports. March 3,1828 Washington: Gales and Seaton, 1828): PP. $3-5$.

22 Memorial of a Committee in Behalf of Cotton Manufacturers of Providence, In the State of Rhode IsIand, February 1,1828

(Washington: Gales and Seaton, 1828), pp. 3-4. 
Arred with both letters and memorials expressing the sentiments of his constituents, Burgas ws well prepared when he delivered his first major adaress on the subject. Speaking before the Comittee of the Whole House, where the bill resided a ter being reieased from the anti-protectionist Comittee on Manufactures, on March 29, Burges raised the voice of Rhode Island in harsony with that of the Harriaburg Convention. Using copious facts and comparative figures, largely supplied by his brother-in-Iaw, the Congressman argued that the British were the one responsible for driving down the price of domestic wools anu woolens. He asserted that alnost 211 of the inport trade since the was had fallen back into tize hands of the linglish, who ware crowdirg vast quantities of woolen goods onto the Arnerican market-but not with the hopes of making a profit for thenselves. The British, he believed, were working with the sole purpose of driving the American manufacturers and growers out of business because of their inability to compete at lower prices. Burges, moreover, stated that only pure protection could remedy the financial losses sustained by the woolen industry, and such protection must be against excesive foreign competition as well as importation. 23

Soon arter the jizl was reported to the House by the

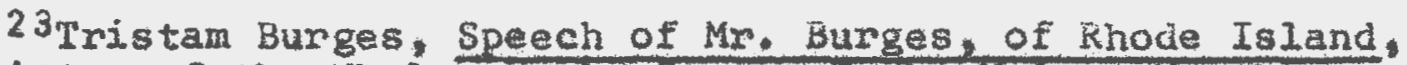
In Committes of the whole on the State of the Union March 29, 1828, on Mr. Mallary's Motion to Amend the Bill on wool and Hovlens (no place: no pub., 1828), pp. 3, 11-16. Tariff Pamphlets, II, University of Rhode Island. 
Comittea of the Whole on April 3,24 Burges again expressed his opinions. Although he believed that the entire bill was a delusion of the hopes of both the farmers and manufacturens, he stressed that he was personally obligated to vote for it as nothing better cruld be obtained. Four days later, after adrocating a tariff high enough to protect the domestic production of inatgo, he reiterated his bellef that the bill, taken as a whole, would probably be more injurious than beneficial to the Eastern manufacturera.25

His thor effort on behalf of the tariff of 1828 came on ApriI 2I, two days before the final Houge vote on the measire. In a speech that the New York Daily Times later estimated to have taken nearly six hours to deliver, 26 the Congressman answered all those who felt thet the protective or Arnerican System would work to the detriment of any section or state. Conjuring up the sharpest Anglomphobian ideas he could, Burges argued for perfect protection of the domestic market for wools and woolens under the American System. Inglish competitors should be driven out of the country because they were trying not only to undersell Aslerican goods, but to destroy the entire American industry. He counseled his colleagues not to listen to compromisers who would

\section{4. 25Repistar of Debates in Cungreas, 20 th Cong., Ist} Sess. IV $2255 \cdot 2323-324$.

26 The New York Da11y Timeg, Ootober 15, 1853. 
oppose the American System by asking for "modified protection" designed to give a "judicious tariff," because to do so would be to play into the hands of the British 1ion.27

As his speech progressed in length and grew in intensity Burges turned from dealing exclusively with the English threat to his personal antagonist, Congressman George McDuffie of South Carolina. During the process of the debate on the tariff, the Southerner in an earlier speech had bitterly assailed Burges, pouring forth a torrent of invective and calling upon the reporters to present his words to the country. Burges replied in the same style and with perhaps even greater acrimony. He accused MoDuffie of having plagarized some of his statements on the finances of the country and criticized his opponent for not having adopted the style of speaking common to scholars and gentlemen. When he intimated that anyone who had heaped abuse on a fellow congressman in a manner like McDuffio's had placed himself beneath the reach of rebuke, Burges drew a sharp rap from the Speaker's gavel and was told to temper his remarks. 28

Turning from a personal rebuke of McDuffie, Burgeg then

27 Tristam Burges, Speech of Mr. Burges, of Rhode Island, In the House of Representatives of the United States, April Ist, A. D. 1828 , on the Tariff (Washington: Way and Gideon, 1828). Pp. 20-21. The brevity with which the Register of Debates (20th Cong., 1st Sess., IV, 2452-453) treats this speech in many instances does the speaker an injustice by deleting arguments and factual material.

${ }^{28}$ The New York Daily Times, October $15,1853$. 
considered the Southerner's argument as to whether American or English manufacturers could supply the domestic wool and woolen markets at the lowest cost to the consumer. With elaborate comparative figures of English and American families engaged in labor, the New Englander arrived at the conclusion that while duties for protection were not a tax on the consuraption of domestic goods they were on the consumption of foreign manufactures. He explained this by saying that the elements of cost in American products were capital, labor, and raw material; while the British had to pay for all of these plus the cost of importation. The conclusion was then drawn that American goods would be cheaper in their own market by as much as sixteen percent, and could compete successfully in any market where they were admitted on equal tems. Indeed, he added, Americans could and must sell domestic woolens in their own market at a cost lower than the British--and to facilitate this the expansion of the sheep industry into the mountain valleys of the upper South was urged as an accompaniment to the higher tariff. 29

Unable to confine himself to economic matters any longer, Burges returned to his ttack on the South in general and George MoDuffie in particular. Calling the arguments

29 Burges, Speech in the House, April 21, Pp. 25 38. 
54.

used by the anti-tariff men and the new Southem sectionalists the foundations of "maddening delusions," the Northerner turned his full attention to the South when he warned that with its new arguments,

The South have but two courses before them. The first, is to join the north and perfectly protect the cotton trade, and secure the most extended domestic market. The second is, to become immediately colonies to Great Britain, which I know they will never; and sell their independence to secure the sale of their cotton wool. 30

Showing a national interest and a belief that the good of the nation would foster the good of New England, a concept many New Englanders had accepted since the early $1820^{\circ} \mathrm{s}$, Burges expressed candid personal opinion on the new tariff. Although not fully certain of its benefits and we 11 aware of its harnful effects upon his home state, he said he expected to support it because it had the appearance of doing good in some areas of the North, West, and South; and because there was nothing better at the time. 31

And support the tariff measure he did. When the final House vote was counted Tristam Burges cast his lot for protection and was among the 105 to 94 majority. It is interesting to note, however. that his fellow Rhode Islander. Dutee J. Pearce, remained alosely connected with his Newport interests and voted against the bill because of the clause

$$
\begin{aligned}
& { }^{30} \text { Ibid. P. } 84 . \\
& { }^{3 I_{\text {Ibid. }}} \text { p. } 90 .
\end{aligned}
$$


pertaining to the molasses duties.32 After the bill had been sent to the Senate for concurrence (where it later passed), Burges stated again his political and economic reasons for supporting the measure.

If they [the House amendments to the tariff bill] do not prevail it will be because the Jackson senators vote them down. Our object is to get a good bill now \& if not now to leave the business in the best condition to be amended. This is the object of all friends of the true American system. It is important too that New England should not defeat this Bill which promises so much to the middle and westem states. It will be instantly said by the opposition that Mr. Adams 8 all his N. England friends are Anti-Tariff. This argument will be calculated [circulated] from any [every] meridian from Maine to Hissouri. It is the settle purpose of all the southern Jaokson party first to overthrow this administration \& then to remove every law of protection so far as they can and retain revenue enough to $g \circ$ on with the government. All true friends of the great American policy must unite if they intend to save the manufacturers of the country.33

He then informed the freemen of his home clty that he was sorry if any of his friends disagreed with his vote, but personal feelings prevented him from voting otherwise. 34

It was not over the tariff alone that Burges managed to raise the ire of many Southern congressmen. Late in January, 1828 , the representatives from Louisiana laid before the House the clains of one of its citizens, Marginy D'Auterive, for injury done to one of his slaves and the subsequent medical

${ }^{32}$ Register of Debates in Congress, 20 th Cong., Ist. Sess., IV, $2731-742$.

33 Tristam Burges to Zacharlah Allen, Washington, April 26, 1828. Feck Mss., Box XIII, No. 6.

${ }^{34}$ Ibid. . 
expenses incurred while building barricades prior to the battle of New Orleans. ${ }^{35}$ Because of the nature of the claim it quickly became a sounding board for the anti-slavery arguments that were gradually developing in the North, especially among those who sought the abolition of siavery. During the debate Burges took a stand on the issue. What he said was not. acceptable to large segments of How England's population. Speaking in reference to those who favored quick emancipation, Burges counseled:

They have indeed zeal--unbounded zeal--but they are entirely without that knowledge and wisdom indispensible to the accomplishment of any great enterprise. Slavery they regard as an evil and Freedom as a good--indeed, as all wise, good, and prudent men in the country regard them. Immediate and universal emancipation is their only remedy for every care and condition of slavery. They say nothing, and think nothing, of the legal rights of the masters thus at once extinguished; nor ask what condition of servitude could equal the wretchedress of a million and a half of slaves at once throw out of the exployment and the support, the protection and control of their masters. 36

He claimed that the South had nothing to fear in gard to the status of slavery, and pledged that he personally would never work to overthrow the rights of any slaveholders in the states where slavery was an established institution. It was here, along with the aggravations over the tariff, that his break with the South cane. The Rhode Islander argued,

${ }^{35}$ Register of Debates in Congress, 20 th Cong., 1st Sess., IV, pp. 1093-098; Bowen, Memoir of Tristam Burges, p. 69. According to the date in the Register Bowen is one year off by dating the D'Auterive claim in January, 1829.

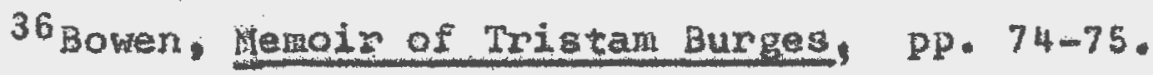


moreover, that the Federal Congress had no right to legislate on slavery in the existing states, as that was a state matter. But not so in the territories, for "except conceming the exclusive jurisdication of ceded territory. the legislative powers of Congress seam confined to raising revenues for comon defense, and general welfare; together with legislation incidental and auxiliary to those great objects." 37 It was this exception regarding the wight of congress to legislate over any matter in the territories that brought a storm of Southern protest down on both Rhode Island and her representative.

Despite his unpopularity in the South and the fact that some elements in Rhode Island had urged a vote against the tariff, Burges continued to maintain close accord with the state's manufacturing element. A dinner was given in his honor on June 12, 1828 in Pawtucket, as a compliment for his distinguished services in defense of the New England outlook and policies; and among the guests was Samuel Slater, the Fathar of Rhode Island's irdustry. After a toast to President Adams, drunk standing with three cheers, the assemblage toasted the guest of honor "as the fearless advocate for the interests of New England" and halled him

\section{${ }^{37}$ Register of Debates in Congress, 20 th Cong.,} lst Sess. IV, 1093-098, 1094. Underining done by author, not in original. 
as the champion of the great national poliey and the friend of the Revolutionary soldior.38 The Congrescman, after the meal was concluded, delivered a vepy shopt address. He reminded his 11 steners, after complinunting Sendtor Nehemiah $R_{*}$ Knight for appportag the tariff bill, that while some in the state disagreed wh the new bill the vote of Rhode Island in Congress should be applaided rather than cengured. For Henry Clay, the prine advosate of the Amertoan Systen and the man to whom Burges was Inoxeasingly giving his political support, he ooneluded "words cannot' honor him; we extend to hin the homage of our grateful hearts."39

As events of the next few years were to prove, however, worde such as these waild becone harder and harder to say. Once again over the tariff they would be entirely forgotten and replaeed with new ones. Hew words that would have an entiraly different neaning.

${ }^{38}$ Hezekiah Hiles, ed, Miles' Weekly Register, Containing Political, Histonical, Geographical, Scientirical, Economical and Blographical Documents, Essays and Facts, together nith Notices of the Arts and Kanuldetures, and a recorc of the Events of the Times, XXXIV, (June 28, 1823), PD. $283-84$. 
THE IACKSON YEARS

Caught up with reourrent illness and still grieving over family losses, Tristan Burges was not very active during the short secoud session of tine Iwentieth Congress. He did hope, noreover, that Adans would be re-eleoted in 1828 and was pleased when the President carnied Rhode Island by a substantial majority. I wher the final votes were in, however, it was seen that Andrew Jackson would be the next President.

In the congressional elections that followed in 1329, Burges and Pearce were again remominated by the National Republicans. The Jackson forces, calling themselves "General Republicans," put forth ex-Republican Congressmen Samuel Eddy ana job Durfee, with the old Federalist representative, Elisha $R$. Potter, and John Dewolfe, Jn. having sore support. Dewolie, a member of a well known merchant family of bristol, had previously served two terms in the State House of Representatives. Diring the course of the campaign numerous charges and counter-charges were leveled. Judge Eddy and Job Durfee aeaused the incumbents of misusing

\footnotetext{
IThe Rhode Island Ameriean and Providence Gazette. November 21,1823 . The vote: 2,180 for Adams; 479 for Jackson.
} 
publle proparty whle in washington and alserted that Parae and Burges were nominated to oppose tha Jaakson Administration in 11 its weasurst-whether they were right on wrong. It was also polnted out that Congressman Bupges had been often sick and missed a good deal of time while Congress had been In sessfon. In answep to these charges the National Republicans ran pritarily on the basis of their past records. Burges' opponent, Samuel Eddy, was changed with being a three sided politidan; originaliy supporting crawfond at his nowinating convention; witchlag to Adams when Crawford was geen loser; and finally desepting Adams for Jacker to recelve the Jackson Party nomination for Congress: ${ }^{2}$

It was ouring this campaign that gurges wrote to Hathan $M$. Wheaton, a Mickford Regublican and candidate for

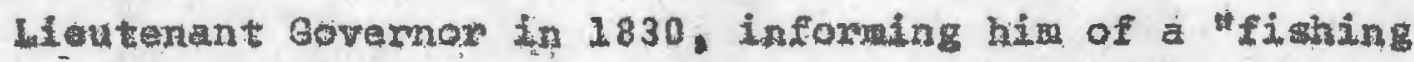
party to bo held at Howland'a Ferry, in Portgmouth near Meuport. Wheaton was unged to have his county represented.3 In an address given at the "flshing party". Burges let his anti-Jackson feelings shine through. He described the Jackson party as the one which "the fence men leaped down

2Tristan Burges. Address. Slanders Refuted, Being a Raply to the Foul and Abusive At Eacks Made on Dutee J. Pearce and ifistam Burges (no place, no date), pp. $3-11$.

Iridtam Burges to Nathan M. Wheaton, Providence, August 6, 1829. Rhode Island HIstorioal Society Mss., XVII, No. 50. 
[into] and joined with those who had sincerely been of that party; and all together, they started for every office in the gift of the President."4 Another electioneering pamphlet announced the party's complete support of Burges and attempted to dispell any rumors that the National Repbulicans were not united behind him. It labored at length to disassociate Burges from any attachment to the Federalist element that might linger in people's minds.

Mr. Burges was first elected to congress by a majority over Mr. Eddy in 1825. The Republican party had, at that time, the controlling power of our elections. The four counties of Hewport, Providence, Kent, and Bristol, all counties which had Republican wajorities, gave majorities to Mr. Burgeg. Washington, the only qounty with a Federal majority, gave a majority against him, and the greatest adverse majority was in the most decided Federal town of South Kingstown. These are matters of fact about which there can be no dispute. They are recorded in the list of votes, in 'figures that cannot lie.' Mr. Burges then owed his election to the Republican Party. In 1827 he appeared again before the gare party. He spread before them a map of his politieal iffe for the last two years, and they again supported him. Another term of two years has now lapsed, and if he is not a Republican candidate now. pray who has changed? Mr. Burges or the Republican Party? Neither Mr. Burges or the Republican Party has changed, but certain men for certain purposes, have taken upon them to apply that much abused title, to a thing too odious to pass without disguise.

As the campaign drow to an explosive close the Jackson

forces brought forth further charges. Since Burges had been

${ }^{4}$ Tristam Burges, An Address to the Landholders and Farmers of Newpont County to the Friends of Megsrs. Pearce and Burges, Holden at Howlands Ferry Bridge, August 1,1829 , 3rd. ed. Providence! Daily Advertiser, 1829), pp. 11-12.

${ }^{5}$ An Address to the Freemen of Rhode Is and by a Republican Farmex (Providence: 1829), PP. II-12. 
born in Massachusetts and owned land in Seekonk it was felt that he cauld not represent his adopted state as well as Eddy-a native son.6 on the day before the election his opponent issued a highly partisan handbill explaining and praising his own stand on many important topics. Eddy boasted of his courage and challenged Burges to gratify his curiosity on the subject "as soon as he pleases." Picked up quickly by the Rhode Island American and Iabeled as a challenge to a duel. Eddy was denounced as unfit for office and undeserving of any votes.? Regardless of the effect this final attack had on the outeome, it was obvious that the National Republicans were behind their candidates. Burges and Pearce far out-distanced their Democratio rivals. 8

At the same time lurges also worked to better the relationship between his home section and the South. Opposed to their stand on the tariff of 1828 , he hoped to establish comercial ties between the Southern growers and Northern producens-and earnestly hoped that Rhode Island and South Carolina could become closer friends both economically and

6he Providence Patriot, August $22,1829$.

7 The Rhode Island American, Statesman, and Providence Gazette, August $25,1829$.

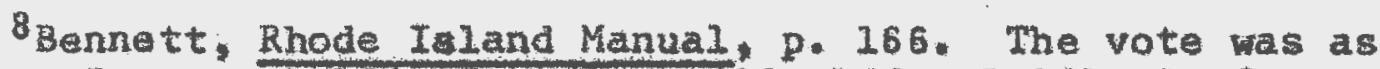
followst Burges, 4,108/ Pearce, 4,328; Eddy, 1,251; Durfee, 1. 226 ; Potter, 581 ; Dewolfe, 203; Scat'.. 33. 
politioally.9 This appeal, however, fell on deaf eare. 18 One of the earliest fators to energe from the House when it assenbled in Ducenber, 1829, was that seotlonal toplos were rife, Hetionnl jealouniss high and partigan warfare undelating. Bogaus of his National Repablican plection and outlook, Burges was more often than not found in opposition to the Jackson Administration.

Taking a relatively lnaetive role in the eaply politieal novenents of the Houte, the Rhode Islander gathered, information and pupport for the attaek on the high tariff he knew would como. Early in Fobruary, 1830, constitutent from Providence expressed auppise that the southern plantars wanted to lower the existlag tariff and had not gragped the idea that the true pollay, even for the south, was sound protection. He appealed for Burges to seak a romon ground where New England as the producer and the south as the conaumer could cove together for mutual beneffts. 11 This was an approaeh the Congressman had tried before, and it had failec.

Burges*, major action during this flat aession of the

${ }^{9}$ Txistam Burges to William Drayton, Providence, June 25 , 1829. In Niles' Register, September, 1829, XXXVII, 24. 10Willian Drayton to Irlgten Burges, Charlestom, South Carolina, August 1, 1820. In Mtles Refister, SeptorabeF 5 . 1829. XXVII. 24.

11 Lexuel h. Arnold to Trietan Burges, Providense, Eebruary 5, 1830. Miso. Mss., Box A, Ar 64, Rhode Ialind Historical soolety. 
64.

Twenty-First congress came as a leader in the fight to beat down the amendients to the taxiff of 2828 put lowth by his arch-fon, George MeDuffie of South Carolina. On ApriI 26 the Southernex moved that ali inereases on the duty on manufactured or raw wool be reduced to the point where they were before 1828, and all increaced on the manufactures of cotton of of goods in which cotton was a whor component also be reduced to the same polnt: 12

Trading argument for argument and parlizamentary move for parliamentary move, the two gldes facod each other squarely In renewed tariff dabat. The axgunent of the opposition forces remed it arescendo the day before the final vote on MeDuffle's amendments. Burges, apoiking for the advocates of pwotection delivered in soning fiveotive an attack agatist both the southern Congressman and his home sate. spoaktas on May 10 in support of a sil for a nore afective

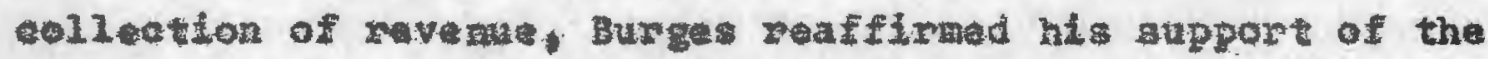
tariff bill of 1826 . He was quitok, howaver, to reject MeDufile's idea that the only way to and wangarestont agalnst the law would be to abolith the law no there could be no violatlon possible. Burges agaln saw Great Britain as the instigeto and the South as the agent in an attempt to dastroy the American protective syster, He, conthned to

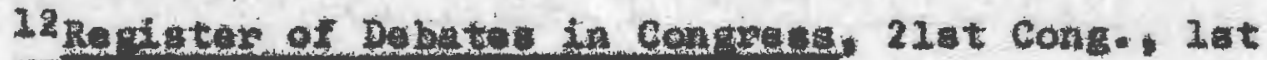

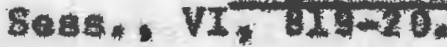


hammer away at MeDuffie's amendwents as designed to abolish the Ameriean Syetem, a system cupposediy detrimental to a ainoxity in the Bouth and whose end would alleviate southern grievanes against the North. South Carolind, it appeared, would only be satisfied when the entire American System was dead and the Unfted States had reverted to the position of economic colonies of England. Burges' anti-South Carolina invective reached its climax in the following attack:

South Carolina, of 11 these States once most devoted to to this Union, go if thou, if thou wit, Leave this brotherhood of republics, this home of eguality in the new world. for allenage in the old, and secondary rights and honors with European royalty. Provide thyself with other pelations; alliance with England . *Alliance with England No mater by what name this connexion [sic] is known to politicians in south Carolina, it will be deemed by all free men in other lands, [as] the ifon and the lion's provider.13

With the Rhode Islander a leader among the opposition, a separate vote was forced on MeDaffie's amendments the fay after Burges" speech. The pesult was a resounding success for the protectioniste. The woolen amendment was defeated by 120 nays to 68 yoas and the cotton olause by a voles vote. 14 Indeed, as the final tariff bill of 1830 arrived, it was anentially the same as the 1828 law-but designed for strieter

13ritan Burges, Speech of Tristam Burges, In the House of Representatives of the United States, When in Comittee of the Whole, May 10, 1830 , on the BIII for the More Ef Fectual Collection of the Duties on Imports, Mr. Medurfle's Amenament to Repeal the Tariff Being Under Consideration. Providence: Marshall and hamond, 1830$), \mathrm{pp}, 3-5,22,25$.

\section{Regateter of Dabates in Congrass. 21st Cong. Ist}

Ses8. IV $184+15$. 


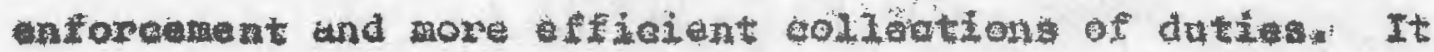
passed the House on May 13 by an overibelning 127 to 40 majority. Eifteon ays later, however, the protectonlate

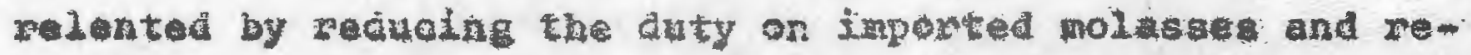

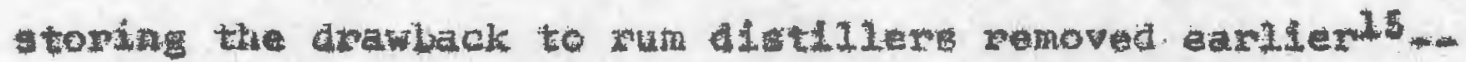
much to the pleasure of foany in Rhode Ialand.

Bumgar did not center all of his politioal attention

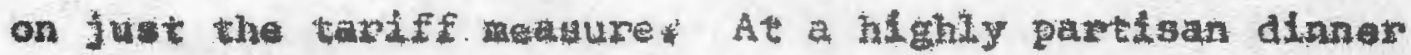
attended by ovap 300 pecsons in Nev York on March 30,2031 , he presented a genexul view of the leading meatrupas and clolnge

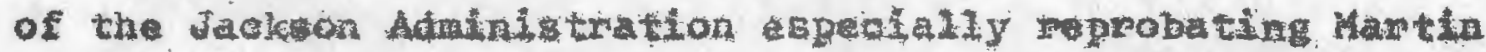
Van Buren for his magament of forelgn aftalrs. Bunges geomed the United Statas foxelgn polley as poorly conducted and playing lato the hands of ather nations. He decried

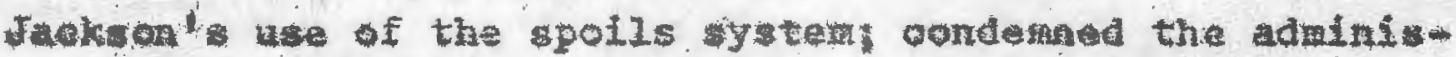
tration's attitude on the Bank af the United States, and denounced the Predident's treatment of the Cherokee Indians as holdang the dounthy un in jugment before the eyes of mankind, Tumntigg from Issues to personalitieg, Van Buren was attacked as a "wlly gentus," a man of "orooked counsels," and prone to "Waiduvellan prineiples." Jaekson was denownced as the destroyer of the constitution and the advocate of tate's rights. Aligning himself with the founder of the Arewioan systen Burges prafsed Henry clay as the "bright sun of the Weat" who had come to save the 
country, and reeeived a toast to clay"s health with three, 81x, and nine cheers.16

In the summer of 1831 Burges and his colleague, Dutee J. Pearce, were renominated on June 22 by a state convention of National Republiaans for a fourth two-yean term. 17 Although they tried to stin up interest in the state by using the need for a high tariff as an 18 aue, 18 it beame obvious as the cumper wore on that the Democrats were going to put up little or no opposition. Indeed, in the August elections the Hational Republicans were cadily vietorious. This one-sided result was due largely to the overwhelning vietory of the National Republican gubernatorial candidate, Lemuel Arnold. and the rest of his prox in the state elections earlier that epring. 19

The argument for keplng the taniff walls as high as possible was again brought to the fore a fen waeks before the Iwenty-8econd Congress convened in December. 1831. Wate in Ootober delegates friendy to high tariff met in Hew York City to counter the demands of the South that the protective system be abolished. The convertion, however, rose to support a high tariff and defended proteation as belng in the

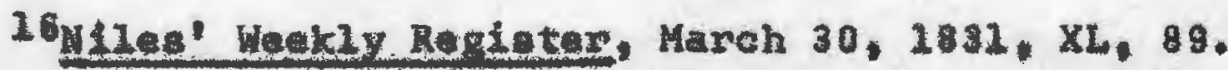
17 Erovidenee Daliy Journel. July $1,2831$.

18 Ibfd. Augret 2, August 9, 1831. 19field, State of Rhode Island, P. 319. 
national interest. To Burges this weeting vas especialiy -igaifleant, for among Rhode Island's delegates were his politleal friends Nathan $M$. Wheaton of Wiekford and Nathanlel Ruggles of Newport, and hLs bether-In-law, Zachariah Allen, the Providence woolen manufacturer. 20

In Washington the tariff diseussion began almost as soon as Congress met. Three bllis were brought forth in the House. The anti-Jackson Southern foraes rallied around a blll proposed by MeDuffie of South Carolina that would reduce the tariff by degrees to a gnneral 12 1/2 poreent level. The Administration bill, ponsored by Congresaman Mclane of Delawgre, was designed to reduce the averaga rates from 44 percent to 27 pereent, mapeal the tariff of 1828 , reduce the duty on raw wool to 5 pereent and on finished woolens to 20 percent, and abolish the "minimum categories" on all but the lowest quality of woolen products.21 Heither side appeared eatisfied. Members of both groups appealed to ex-President Adans, now a representative from Massachusetts and chairman of the Committee on Manufactures, to work out a compromise solution. On May 23 Adams introduced a modifioation of the Mclane bill, which while based on the administration measure, changed some of the detaile. Whth thls compromide plan before

${ }^{20}$ Address of the Friends of Domestic Industry, Assembled in Convention, at New rork, October 26,1831 , to the People of the United States (Baltimore: 1831 ), PP. 1 , 35. $40-41$.

21E1210tt, The Tariff controvarsy, PP* 258-59. 
the House, MoDuffie's origlnal b11, ohling for draste reduetions was quiekiy done away with, but the protectioniste still despatied for the high tartf.22

While the parliamentary battle was raging over the type of plan that should be used to out the tariffs. Burges was representative of the despaiv that the protectionist element felt. Late in February, soon after HeDuffie's prom posal was finot made, Bupges expreased fears for the tartff and of making any concessions to the south. He let it be known that he himself would be unable to aceapt any compromine that would abanden the system of encouragement*

The South will again play, or attenpt to play the Missouri game with us. They will thpeaten to dissolve the Union, if we do not yield. Some nen are alarmed: more may be but you may be assured that R. Island w11 not hineh. When it aones to the wrot have other sop to throw the. * . South, whout giving hill the bones of the Ameriean System to gnaw. 23

Durlig the course of the debate. Burges kept wall informed of the foolings in his hom state. In a letter from his brother-1n-1aw he learned that the state General Assembly had unaninousy coneurred in protest agalnst the proposed tapiff alterations. Indesd, Burges was told that the old Federalist turned Demoexat, Elish R. Potter, was on the verge

${ }^{22}$ Ell lott. The Tariff Controversy, D. 259 claude 6. Bowars, The Party Batties of the Jacksan Period (Boston: Houghton Miffin Company, 1922), Pp. 193-95.

23 Thista Burges to Zachariah Allen, Washington, Fobruary 26, 1238. Peok Mes., Box XIII, Ho. 23. 
of abandoning the Jackson administwation over Its tariff polieles. 24

Voleing the desires of the October convention in New York and of his friends in Rhode Island, Eurges delivered a majow address on June 16,1832 against the proposed compromise bill of Adang. The Congresman pleaded with the members not to overlook the wolen induetry and trade in their desire to proted others and once again brought up the spectre of American industry being deliberately destroyed by England. Calling the proposed bl11 a conmuling sword, whetted for claughtex" he reminded his colleagues of the terwible results it would have, and rade a last plea for perfect protection as the necessary prosexver of domestic induteies. 25 Despite his efforts to forwtall a final vote and his speech appealing for rejection of the proposal, the the fop tariff reduction was too great. On June 28,1832 the b111 pasted the Botse by 162 to 65,26 then went guidkly through the senate to be ejened Jackson on July 14,27

It was not just the tamiff battle that concened Furge howevar. Both he and Pearce roluthid forces in April to press

24tachariah Allen to Tristam Burges, Providence, May 7. 2832. Peok Mas. Box XIII, No. 24. 25 Rerister of Debates in Congress, 22nd Cong., Iet Sass., vIT工, 36t5-65.

26 IDIA. pp* 3836-831.

27 stanwood, Amentoan Tanlfe Controveries: pp. 381-83. 
for a federal survey of Narragansett Bay with a view to finding the best location for a naval base. Although they argued that such a measure was of national concern, they were opposed. Many in the House did not want naval appropriations attached to bills for civil expenditures as its proponents advocated. Upon the favorable recommendation of the Comattee of the Whole it was defeated 80 nays to 60 yeas-with Burges and Pearce in the minority. 28

In the waning days of the first session of the TwentySecond Congress Tristam Burges found himself turning politically towards the ranks of the anti-Jackson forces. This became evident on July 2,1832 when Burges was among the House majority that voted to recharter the Bank of United States in the hope of using it to defeat Jackson in the forthcoming presidential election. 29

The sumber between the first and second session of the Twenty-Second Congress was filled largely with tending to neglected business transactions in Providence and in campaigning for the defeat of President Jackson in the fall. Opposed to Jackson because of his attitude toward the bank, the refusal to support internal improvements, and his lowering

\footnotetext{
${ }^{28}$ Register of Debates in Congress, 22nd Cong. 1st Sess., VIII, $264 \overline{9-650 .}$$$
29 \text { Ibid. } 3851-852 \text {. }
$$ 
of the taxiff, 30 Burges also denounced the spoils system as belng feudalistie. He urged the National Republieans, Masons. and Anti-Masons to "fom a ring around the constitution" and "move onward to the redenption of our common country" by voting the President out of office. 31 Although Hanry Clay, the Nafional Republican candidate, carpled Rhode Itand by a 684 vote majority, 32 it was Jaekson's ultimata viotory in the ontire election and the events of a nulliffeation convention meting in south Carolina that set the sage for the storray second session of the Twenty-Second Congrese. 33 When Corgxegs met for its second session in December. clay had been defeated, but there wa hope that between the Northern aupport of protection and the general horror of nullifleation the tarlff would come through unharmed. The whter that followed was one of exattement: Jackson me the developing Southorn arisis with a mixture of fimmes and concesston, and isaued a proelamation denouncing nullifeation

30 Tristan Burges, A Statenent of Some Leading Principles adopted by General Jackson, and the effects of these Principles and Measures on the Union, Prosperity and Constitution of the American People. An Addregs to the Citizens of Rhode Island, In answer to Their Call on the Delegation of this state in Cong-

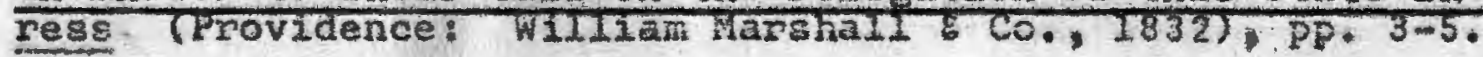

3iTritran Burges. A Brief Sketch of the Rerarks Delivared at East Greenwich at a convention of Mational Republiauns on the 23ra of August 1832. Trovidence! Williand Mrahan है Co." (8832), PP. 6,15 .

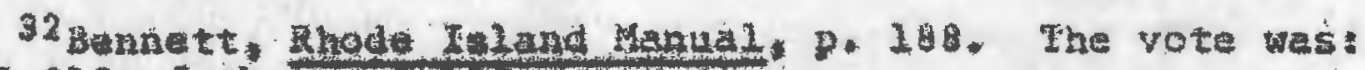
C1ay, 2,820 , Jackson, 2,126.

$33_{\mathrm{A}}$ good sumary of the events and ldeas leading up to the Hullification Convention is prosented in Irederic Baneroft's Calhoun and the South Carolina Mullifleation Movenent (Baltimore: The Johns Hopkins FTess, 1928). 
and warning South Carolina that the federal laws would be enforced. While the North rang with applause for the President, South Carolina answered in a spirit of defiznce.

Meanwhile, in his annual message to Congress, Jackson discussed the tariff problam at length and argued for a reduotion in all but the most essential itehs. 34 on jecember 27, 1832, the ardent free trader George C. Verplanck of New York, chairman of the Comittee on Ways and Means, brought forth a bill which was understood to have the Presidant's approval.35 In Verplanck's bill wool and woolens, as usual, were handest hit. The duty on wool costing roro than eight cents a pound was to be reduced to 35 percent with no specific duty. In March, 1834 it would be lowered to 25 percent and a year later to 20 percent. Woolen maufactures were hit equally hard. Goods charged with 50 percent in 1832 were reduced to 40 percent for the first year, 30 percent for the second, and thereafter to 20 percent. Discussion of the bill began on January 5,1833 . It continued almost daily until February 12, when a new series of propositions arrived from the Senate. 36

iost of the protactionists in the inouse, while they

\footnotetext{
34EIliott. The Tariff Comtroversi, pp. 263-54.

35 Ibici., p. 264; Stambod, Mmeriaan Tariff Controversies, pp. 390-91.

${ }^{36} \mathrm{Stanwood,} \mathrm{American} \mathrm{lariff} \mathrm{Controversies,} \mathrm{pp.} \mathrm{390-99.}$
} 
would cordially support the President's desire for a Force bill directed at South Carolina, would resolutely resist any changes in the tariff. Standing as fimly as possible, they regarded the Verplanck bill as a death blow to the American System.37 During the period this bill was under consideration, Tristam Burges delivered a major speech against it. Speaking all day Saturday, January 26, and concluding on Monday, he vigorously defended the interests of New England. With lavish use of facts and figures he attempted to show that any tariff cut would do more hanin than good to the nation. Expressing a fear that many in the Northeast felt, Burges viewed reduction of the tariff not as a necessity, but as a weapon in the war being fought by Southern slave owners ageinst the free whites of the North in an attempt to destroy their higher wage scale. His greatest objection to the bill, however, he stated bluntly and openly:

This bill calls for concession, nay, for submission to South Carolina; to admit, adopt, and incorporate her ordinance and her law into our system of legislation. Will this preserve or destroy your constitution [sio]. cement or dissolve our Union? Sir, mingle nullification with the pure principles of your enactments, and, were your constitution [gio] strong and impenetrable as iron or [as] adamant, this vile alchemy will dissolve into impalpable gas every link in the chain of your union. 38

Burges continued to oppose any tariff reduction even

37 Niles' Weekly Register, January 5, 1833, XLIII, 297.

${ }^{38}$ Register of Debates in Congress, 22nd Cong., 2nd Sess.. IX, 1385-1413. 
when a compronice bill proposed by his political ally, Henry Clay, was substituted for Verplanak's bill on February 22. Although Clay's bill differed from Verplanck's bll1 only in postpoling the day when the lowest rates would reach 20 percent, 39 burges could not gesept it. On February 26 he opoke out against this compromise lowerlng of the tartff. He reminded the House of its unanimous aceeptance of a pasolution frow the Rhode Island Gonezal Assembly earlier In Januery condenning any tariff cuts. He repeatedly counseled the west not to be duped by the south, and meminded them of their bonds with the North. As for the south itself. Burges again called forth the vialon of free white working wen in the North laboring for a wage as low or lower than the poorest Southern slaves-m situation he felt was bound to result if the bill passed:

It was for the proponent of the compromise plan that Burges saved his greatest abuse. Although he had praised Henry Clay on numerous previous oceastons, he could now do Iittle le but denounoe hiw. He referred to cilay ast - our star in the veot [sic], our sur in the - town, our bow of promise ln the tempest of our times. He has been the hero of our talesi his deeds the argunent of our discourses; his glory the song of our festivals. Whose name was ever so frequent in our floting eups! Who,

\section{${ }^{39}$ Eliliett, The Tarife Controverey, p. 265, Lyneh,} Iifty Years of Pard rensate, P. 7s4* 
like him, ever sat with us at the great political table! we have together taken salt from the same stand, bread from the same basket; he has, with us, dippad the political sop in the same dish; and now he has liftea up his heels against us, and we are delivered into the hands of our adversaries. 40

An observer of the speech, Elisha Reynolds Potter, Jr., was much more succinct in conveying Burges' meaning to Rhode Island. Indeed, he wrote his father that MMr. Burges cut Mr. Clay very hard, called him a Judas.. " 41 on the day the speech was given, the House took its final vote on clay's bill. Burges, defending his state's interests, opposing any concession to South Carolina, angered at Clay, and toeing the protectionist line, could not compromise. He voted against the bill. His vote was to no avail, however, as the measure passed 119 to 85.42

Although Burges was in the party of opposition to Jackson, he supported the President's stand against South Carolina's nullification. He argued against any postponement of the Effective Revenue Collection (Force) Bill, but made it clear he was working for the good of the country and not to aid the administration. After attempts to postpone it failed, Burges and Pearce both voted for it when it passed.

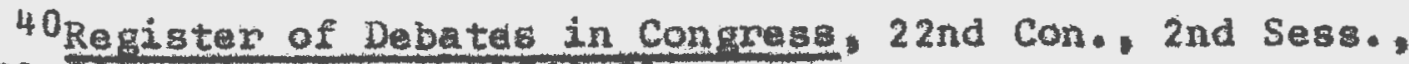
IX, 1781-791. Quote. PP. 1789-91.

${ }^{41}$ Elisha R. Potter, Jr. to Elisha R. Potter, Sr., Washington. February 26, 1333. Potter Mss., University of Rhode Island.

42 Register of Debates in Congress, 22nd Cong. . 2nd Sess., IX, $1810=I 811$. 
the House on March 143 -mperhaps as a way of getting back at the South for forcing a tariff reduction.

Burges, however, could not support Jackson on irost of the issues he personally deemed injurious to the country-much as the war on the bank. When the House, March 3,1833 , passed a resolution "that Government deposits in the opinion of the House may be safely continued in the Bank of the United States," Burges supported the measure. 44 placing himself in opposition to the President, he assumed a position from which he was not often to retreat during the remainder of his congressional career.

To Tristam Burges, 1833 was also an election year, and this meant getting re-elected during the summer secess. The National Republican Convention, held early in June, unanimously nominated him for a fifth term but withdrew its support from Dutee J. Pearce. In Pearce's place they put up Nathaniel $S$. Ruggles of Newport, Burges" political ally who attended the New York tariff conference in 1831.45 on the last day of June the Democrats met and appointed a select comittee of five to nominate candidates at a later date. By August 7 the
${ }^{3}$ Ibid., PP. 1821-1903.
44 Ibid. PP. 1922-936. The vote was 109 to 46. 45 The Frovidence Journal, July 1 and August $10,1833$. 
pro-Jackson Republican Herald announced its support of Wilkins Updike of South kiragtom and Nathan 3 . Sppague of Smithfield.46 More was yet to come. By mid-August Burges's name appeared alone on the Republican prox aftex Rugales had decided not to run. As it wes then less than two weeks from the election, the party chose to leave the post vacant. 47 To this list of orndidates Dutee J. Pearce added his name as the "People's Candidate" and Adbert C. Greene, Henry $X$. Cranston, and Wathan F. Dixon entered as un-nominated National Republicans. 48

As the campaign itself entered its final weeks, the hottest battle was waged between Sprague and Burges. While Burges ran primarily on the basis of his pecord, his opponent did just the opposite. Speaking for sprague and the Jackson Party, the Republican Herald charged that for Rhode Island to gain a share in the benefits of federal legislation "she nust muzzie the lips of professor Burges, and kop hill as silent as the marble pillars that beautify the Legislative Hal18."49. The Democrats, moreover, compiled a list of reasons why Burges ghould be defoated: he had grown "purse-proud"

\footnotetext{
46. The Republican Herald, August $3-7,1833$. 47 The Providence Journal, August $15-17,1833$. $I, 568$.

${ }^{48}$ Carroll, Rhode Island. Three Centuries of Democracy.

${ }^{49}$ The Providence Journal. August 8,1833 ; The Republican Herald, August 10-17, 1833.
} 
and aristooratical, te regarded his follow citizen with rospect only at lection time; he alvocated a aourse favorable only to the ctate's manafacturers! he was not artend of the farmers, he was not wally a Republican; he comitted the political sin of working to elect anti-Jackson candidates in Maseaohusetes he had opurned Henry clay; and he pereleted In the outwoded bellefs that had brought hin to power despite changes duphing hig years in Congoess.50

The Jackson wer hoped that by courting the support of the state's Anti-kasonic faction they could defeat Burges. As early as Octoper. 1831 the Democpats had galned AntiHasonic support when they dominated a state committee that Investigated Mogonid wotivity and recomended that all Masonio institutions discontinued.51 Inded; five days before the cleotion the Democrats still feIt that the Ant-Masons pould go agalngt Burges. As his opponent mote! ". "there is faix prospect of the Anti-magony going in grat mber [gie] for se 8 as far as I know they will go againgt Burges I think under these ofroumsanee ay chances to defoat him are very good." 52 Despite these atterpts to oust hin the incumbent

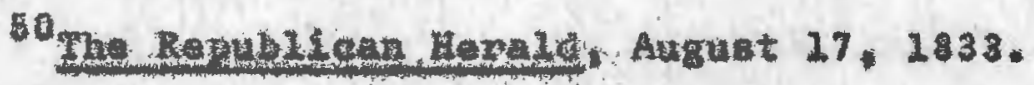

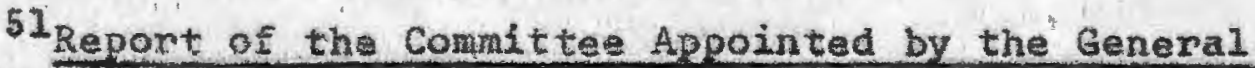
Assembly of Rhode Island to lavestigate the Charges Agarist Freamasonny \& Masons in Sald state: To fethen with all the official Documents and Testrimony Relating to the subject. Trovidence: Whilam Marshall, 1832), pp. 3, 121-24.

52 fathar B. Sprague to Elisha R. Potter. Smithfield. August 22, 1833. Pottor Mss, University of Rhode Island. 
was able to ride his record to victory and was elected on the first trial. Since no other candidate received a majority in the August election, a by-election was held in November, and Dutee J. Paarce emerged the victor-but this time as a member of the Jackson Party.53

No sooner had the Twenty-Third Congress convened than Burges took a decidedly anti-administration stand. In the first session the fight was mainly over Jackson's bank policy, and it led to serious rupture between Burges and his long time coileague, Dutee J. Pearce.

The split between Burges and Pearee began in midFebruary, 1834. On the seventeenth Burges presented a memorial from 1,065 voters in Providence favoring the veestablishment of the bank, Pearce, now with the administration, attacked Burges, denying that 1,065 voters could represent the true feelings of a city of 19,000; and saying that many of the signatures seamed to be in the same handwriting. While Burges expressed regret that his colleague had to sever their ties of friendship, he continued to support his memorial, Pearce insisted that in the past three years the majority of people in Rhode Island had grown opposed to the bank and he no longer felt that cordial relations between him and Burges

${ }^{53}$ Field, History of Rhode Island, p. 324. The August results were Burges, 3,162 ; Pearce, 2,078 ; Updike, 1,904 ; Sprague, 1,499; Greene, 557, Cranston, 325; Dixon, 167; Scat'., 227. The November results were Pearce, 2,152 ; Dixon, 1,705; Scat'., 25. (Manual, p. 167.) 
were possibze. 54

Late In March four resolutions concerning the federal deposits were presented in the house: 1) that the Bank of the United States should not be rechertered;2) public deposits should not be restored to the bank; 3) state banks should be continued as places of deposit for pubile funds; and 4) a select comittee be appointed to invegtigate the functions of the bank and report to Congress when it had combleted its study. 55 The debates apound these motions led to futher alienation between the two Rhode Iolanders and drove Burges further into the anti-jackson ranks.

On March 31 Burges presented two more menonials, one from Patterson, Maw Jersey, and the other from Sxithfield and Cumberland, Rhode Island, aking for the rochareer of the bank and pestoration of deposits Fearce countered with a letter from his home stato saying the Rhode Igland memorial had not been algnad exclusivaly by poople of the towns mentioned, but by outgiders for political purposes, Burges flatly charged that Pearce's letter was a forgery, and a debate of "a very lengthend and reariminatory nature arose batween the two honorable members from Rhode Island." The dispute was temorapily ended by George Evans of Maine when he

54The Congressional Globe: Contairing Sketches of the Debates and Proceedings of the Twenty Thind Congress (Washington: Office of the Globe, 1835 ), 23 rd Cong, Ist Segs, I, $181-82$. 
moved that Burges memorials be printed and laid on the tabie. A thind memorial from Nemport was then presented with no opiection from Pearce.\$6

$$
\text { Burges' anti-Jackson stand continued during the vote }
$$
on the four bank resolutions in early Augugt. On the proposal tiat the bank should not be rechartered he voted no and lost 132 to $83-m$ with Pearcs opposing him. The rosolution not to restore deposits was also carried 118 to 103 with Eearce on the Jackson side. Burges remained silent. On maintaining depostts in state banks Burges again voted against Jackson and was defeated 217 to 105-with Pearce again in the majority. The reolution for an investigation, however, found the two Fhode Islanders among the preponderant 171 to 43 riajority, 57 but for different reasons. While Pearce felt the investigetion would expose the evils of the bank, Burges was sure it would be vindicated.

Even after the vote on the four resolutions had been taken in Jackson's favor, the split between Burges and Pearce continued. When on April 14 Burges presented a memorial from Proviuence piotesting the removal of bank deposits, Pearce countored with menorials from lrovidence and Existol favoring the Jackson program. 58 In mid-June the Democratic House also kilied two benate resolutions disapproving the withdrawal of

$$
\begin{aligned}
& 56 \text { IDid., P. } 282 . \\
& 57 \text { Ibid. P. } 292 . \\
& { }^{58} \text { Ibid. PP. } 308-09 .
\end{aligned}
$$


public deposits frow the bank and direating that such deposits be restored. Both tifhes Burges and Pearce voted in opposite directions, the Republioan in favor of the Senate resolutions and the Democrat opposed, 59

The only show of unity between the two antagonlete from Rhode Island did not come until four days from the end of the sesalon, and was necessary to prevent possible politioal repmpeusions at home. Both men supported an appropriation amendtant allowling pay to Rhode Island's Ellsha R. Potter, Sr., for each day of attendence in the senate proceding his renoval after a contested election, 60 Burges' support was given despite the fact that he had earnestly worked for Potter's defeat before the eleotion was held.61

The nost inportant battle in the ahort second segsion from 1834 to 1835 arose over Jackoon's attempt to compel the Franch government to observe her obligations under the Treaty of July, 1831. According to the stipalations, in compensation for damages to the United States during the Napoleonie period, France was to pay five million dollars in ix annual instaliments in return for a reduction of the

5'Ibid. P. 445. For Burges" position in the bank controverey Be also Arthur M. Schlesinger. Jx., The Age of Jackson (Boston: Little, Brown and Company, 1946) p.108. D. 474.

60 ine Congressional Globe, 23 rd cong*, lst Sess., I,

617platan Burges, Reasons Why the Hon. Elisha R. Potter Should not be a Senator in the Congress. By One of the People (Providence: 1834). 
duty on French wines. It was the President's contention that he had lived up to his half of the bargain but France had not. Under such ominous conditions, and with the majority of the representatives favoring continuednegotiations only with concurrent military preparations, the House became engaged in heated debates reflecting the excitement of the times.62 When on February 28, 1835 , Representative Cambreling, a New York Democrat, resolved "that in the opinlon of this House the treaty of the 4th of July, 1831, should be maintained and its execution insisted upon dt all hazards," Tristam Burges rose in opposition. Burges counseled the House against a war with France over the collection of the clains. Although he felt that every individual in the land should insist upon having the treaty carried out, he thought the House should be extremely cautious in any actions that might lead to hostilities with France. After observing that there were slim grounds on which to call for military actions, he noted that once the United States had been willing to pass over the insults of France for a monetary settlement it would be an inglorious disgrace to go to war. He would, however, not object to any rasolutions on the subject that did not involve the use of force. Burges feared that any ultimatum to the French of pay-or-fight would put France into a position where "she would be cowardly indeed if she should pay the

62 Bowers, Party Battles of the Jackson Period, pp. 
money under guen circumetances." 63

The outoome of the fight was the adoption on March 2 of a resolution that insisted on the malntenance of the treaty and in favor of nilitary preparations. Adopted that evening the House resolved that "the treaty of the 4 th of July, 1831, should be maintained and ito expoution insisted upon." The vote was an unanimous 212 to nothing, but the name of Tristan Burges was not among those rocorded. 84

At three A. H. on Tuesday worming, March 3, 1835 , speaker John Bell of Tennessee adjourned the second session of the Twenty-Third Congress. With this action the career of Tristan Burges as a member of the House of Representatives was ended. 85

63 The congressional GLobe, 23 rd Corg., 2nd Sess., II, 64 Ibid., p. 323. 65 Ibid* PP* 328-33. 
A WHIG IS DEFEATED, THE ELECTIONS OF 1835 and 1836

Politically 2835 began on an inauspicious note for Tristaja burges. Late in 1834 it had been sumored around ibshington that he wauld seek election to the senate from Rhode Island as an anti-Jackson candidate. Burges hoped to replace Sanator llehemiah $R$. Knight, whose tern would expire March 3,2835 , and who had announced he would not saek reelection. I Late in January the Grand Comititee of Rhode Ialand, the House and Senate acting together, failed after twenty billots to elect a senator, and postponed further action until May. By that time, however, Senator Knight was anxious to get back into the race. fs the nominee of the anti-Jackson forces he defeated Elisha R. Potter, 41 votes to 38 . Burges, receiving only one vote, was disappointed at being set aside by his party for knight and at not being elevated to the national upper house. 2

Since he was vigorously opposed to "King Andrew $I_{3}$ " it was not at all aifficult for the Federalist-turned-National Rapublican Iristan Burges to follow the general shift into

Iniles' weekiy Register, XuVI, 396.

2Field, State of Rhode Island, I, 327-28. 
the newly oreated Whig Party that had been developing since the can $1830^{\prime} 8$. Indeed, contamporaries recorded that the Whig Party was made up of National Republicans, Anti-Masons, pro-bank Jakkson men, Webster Federalists, and a lange states pights element who felt the federal government had no right to coerce sovereigh state and were violently opposed to Jaekson. 3

That Burges had joined the Whig ranks becane evident during the gubernatorial and genatoplal eleations then going on. On March 3,2835 he told a well attended pathering in Providence that if the Whigs triumphed in the pring they would also win in August. This would, he assertsd, Insure the defeat of Jackson because the Whigs would control Congress and be in position to lect a new president when the issue, according to Whig strategy, was thrown to the House. 4

At the tate Whig Conventinn on June 24,1835 Iristam Burges and Henry $Y$. Cranston of Newport were unanimovely chosen as candidates for the Twenty-Pourth Congress.5 The

${ }^{3}$ Lynoh: Pifty Years of Party Warfare. p. 467.

${ }^{4}$ Niles' Weekly Register, XLVII, May 2, 1837, P. 147 , Tristam Burges, Speech of Mr. Burges, Delivered at a Meeting of his fellow citizens, in the Town house in providence, on Friday evening, March 3,1835 (Providence: $\mathrm{n}, \mathrm{p} ., 1335$ ).

5 The Providence Journal, July $2,1835$. 
next day Jackson forces, now called Democrats, put forth the ex-Republican Dutee J. Pearce and Wiliian Sprague, Jr. of Warwick.6 The campaign that followed has been called one of the bittereat in the history of Rhode Island politics.7 Although the Whig dominated City Council of Providence resolved that they had complete confidence in Burges and approved of his and Cranston's nomination, 8 such actions Wene not to be the major features of the campaign. With the Providence Journal vigorously supporting the Whigs and the Republican Herald standing for the Democrats, the battle became a personality contest with neither side stiaking strictly to the issues.

Taking the initiative, the Jounnal reminded the Whigs that unless they were active and sure to vote on election day Pearce and Sprague, with "a retinue of servile demagogues and independents," would be elected. If the state was to keep its influence in Congress, the Whigs argued, it would come only through representation by a man of power, intellectual force, and moral wisdom. Using the argument that Rhode Island must replace what it laoked in population with personal force,

\footnotetext{
The Republican Herald, July 11, 1835.

7 Carroll, Rhode Island, Three Centuries of Democracy, I, 568 .

8" Proceedings of the Providence City Council, July 6, 1835," in The Providence Journal. July II, 1835 .
} 
they atrongly favored the election of Tristan Burgen.9

Indeed, the election of Burges and Cranston was necessity to assure the selection of a man like Massaghusetts Daniel Webster when the presidential election was thrown into the House of Representativas as the Whigs planned. This, the Jounnal felt, wa far better than the election of Jadken's hand pioked succegser, Martin Van Buren-m min Hege

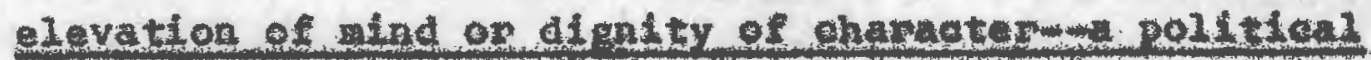

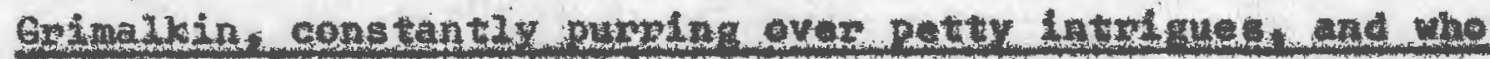
spends time in devising soheme for hts oun advaneenent." 10

As the campaign prokpesed the greatest clashes came between Burges and Sprague and Burges and Pearce. The Democrats, moreover. wre trying desperately to unseat the five term incumbent, Continuing the attak, the Journal repeatedly asked if spregue was qualified to roplace Burges and then answered its ow question with a resounding "no."

The friends of wa. Sprague, Jx , pretend that they have some hope of leoting him to congress over Iristan Burgea. Reader's do not laugh, Hold in, if you wan, your ribible propensities.---Wh. sprague, Jr. in preference to Tristam Burges $1 / 1$--the Iden is too pidieulous. to be entertained for a moment. It is a libel upon the good sense of our freemen-i-it is a slander most foul against our tate. 11

Ibld, July 27, 30, 1835.

10 Ibid.. August 6, 2835. Quote from the Journal, Juiy 30, T835.

IIItat, Auguet 6, 7, 1835 . 
It was feIt, moreover, that both Sprague and Pearce belonged to the elass of politicians who advocated anarahy and confusion rather than $l a w$ and onder. 12

The Democratio pess did not sit ldy by during the Whig attacks, Besldes comparing Burges to his mival, William Sprague, and flnding the inoument lacking in the qualitiod Sprague possested the Republioan Herald began to drive home a now issue, It was wall knowa, thoycontended, that Burges consented to run for reeleetion only when his party refused to levate him to the senate. The conclusion wa drawn for the voters that Bumges now regarded the House of Representatives as a secondary position and was insulting the pppple by running for it 13

Burges was also condenned for his anti-jackson stand. The Herald noted how the Whigs were scheming to have the presidentill election thrown into the House to insure Van Buren's defoat. In doing so, it was argued, Burges was attempting to subvert the will of the people through an undemocratic action. For his work. In trying to uphold the Bank of the United States, he was deemed more a member of a "Federal Bank Party" than Whig 14 The herald reiterated, moreover. that Burgas' role in his own party had

$$
\begin{aligned}
& { }^{12} \text { Ibid, August } 10,2835 . \\
& \text { 18 The Republiakn Hexgld, Angust 12, } 1835 . \\
& \text { 14 Ib1G. Auguet } 13,1835 \text {. }
\end{aligned}
$$


degenerated since his tailure to eapture a Senate seat to the polnt where he had beome the "pack-horse" of hls party's desires. Because of advancing age it was felt that he had becone little more than the "pliant tool" and "pilaything" of the party leaders, 15

Baptloulaniy bitter againet Sprague because he represented new lement in polltios after bedoning wealthy in incustrial ventureg. 18 the Whigs contlnted their attack. When

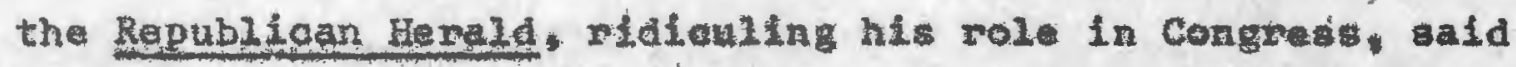
of Burges:

Tristan is a real thund'rar. Truapet tounged, a magnus homo.

And one nust be a sutzus bitnd'rer. Not to feel his oratoro. Did he not once floor Macbuffie As flat as 'or Mae did cufee?

And did he not lay on MacDuff Till Mac oried "hold' and gald "enough"

onl once he took to battle Dutee About memorials and the Bank,

But Dutee trounced him as did he Buthten And down his seat the hero sank ${ }^{27}$

the Journal 10st no time in popying; Noting thet furgen had been on the Rhode Island scene for many years and knew the conditions in farming and wanufeturing, the thig paper countered:

Sone say, that Irlstan Burges Don't know a thing or two:

But I say he forgot More than Spragtie ever kneu.

15 Ibid. August $19,1835$.

1.8 Carpall. Rhode Is land. Three Centuries of Damecracy.

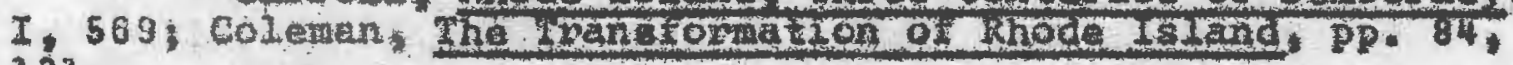
231.

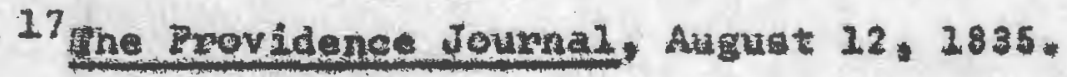


He knows more about farming

Than Sprague and Dutee both;

Talk with him and you will see

That what I say is truth.

He knows" to, by experience, well

As any in Pawtucket:

Dutee himself, don"t doubt his skill,

To mend a leaky bucket. 18

The poems and good words in favor of the incumbent were of little avail. Burges, after serving ten years in Congress, was beaten by 148 votes.19 Although some have gaid his election was lost because of his break with clay, 20 and the Jounnal was later to call it a fraud, 21 a number of other reasons wex given for the defeat. Gloating in their viotory over Burges and Cranston, the Herald gave one reason, although highly partisan, of why Burges 10st.

Even Tristar Burges, the idol and oracle of the federal party, has condescended to become a eulogist--to stand in public and sound $h-s$ [sic] own praises--to boast of his own acts, and with the most consumate gotism, excusatto oniy as the folly, of an old man in his dotage, to compare himself with other men, and strike the balance in his favor. 22

The conduct of his opponents must also be notod. Besides

18 Ibid. August 13, 1835.

19 Field, State of Rhode Island, I, 328.

20 Gordon F. Harrison, Lineal and Collateral Ancestors of Theodore Francis Green who Served in the American Congress (Washington, 1955), p. 53 .

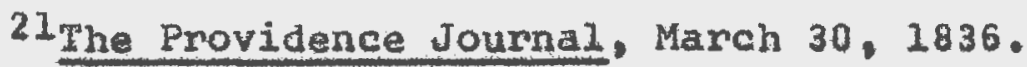

22 The Republican Herald. August 29, 1835. 
being among the walthiest induatrialists in the state, the Sprague family were also pesourceful eleetion manipulators. Through the supervision of their employees' ballots (there being no secret voting as get) they were able to secure the election of their ow candidates on memers of the fanily itrelf. 23 The defeated candidate himself added a major reason. Four day after the election he wrote:

Already the [anti-slavery] question has been mingld [sie] with politioks [sie] I doubt not that some men have voted against me on the 25 th inst. because I was agulnst the abolitionists. Mn. Sprague, Jr. My opponent, is a Van Buxin [sic] man it it understood that he will vote for the abolition of alavery in the D. of Colombia. I have noidoubt, that Van Buren is seoretly formenting this oxeitement in New England that he may profit by our divieions. Cowe what wi1, I have set my face against whatever may peril the constitution, the union or the peace of prosperity of our country. It seems almost enrtain, that 8 prague and $D . J$. Pearce are eleeted the representatives of $\mathrm{R}$. Is land in the next Congress whatever Van Burin. [ste] direote, they w1I w1Ilingly endeavor to de. 24

Despite his defeat in 1835 . Burges was stll among the most prominent Wige in the state. Indeed, he commanded anough loyalty to be placed at the head of his party's prox in the gubernatorlat elections in the spring of 1836 . Running with

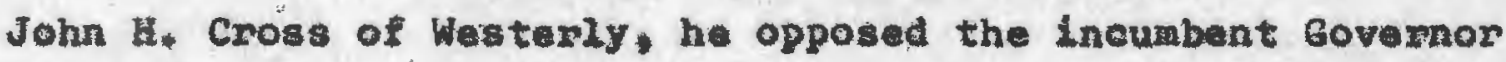
John Brown Eraneis of Warwiak and Jeffrey Hunter of Exeter. Burges' opponents, moreovar, ran on both the Republlean, 622.688 .

23 colemudx The Transformation of Rhode Island, Pp.

24 Thistan Burges to H. L. Pinckney, Providence. August 29, 1835. Peek Mes*, Box XIII, Mo: 35 . 
Administration, and Parmere' Prox as well 28 the Antimaconic Republican Proz.25 Using alleged frauds in the election of 1835 as their major issue, the whigs again tried to run Burges on the basis of his record. His exertions in favor of the agrioultural, manufacturing, and commeroial interests of the state were emphasined and his unswerving opposition to the "eoreuption" and "gatronage" of Jaakson were pointed out. Burges was agaln made out to be the friend of the Revolutionary War vetemans, and his defense of the old soldiars on the floor of Congress inas Iauded.26

Regaydless of 'boasts by Burges' supporters that he could not be beaton, the Demoorato felt that his polfileal magnetion had passed its zenith with his defeat in 1835. They didn't expect him to drav nearly as many votes in the forthcoming contest as he had year earlier. As tarues, the Demoeratid reminded the voters of Burgen' statements made in 1835 regapdng lavery and the untl-ndavery movements in the Distulat of Columbla." He was declared to be unfriendiy to the abolitionist cause. 27

The Demoxwats continsed to hammer away at Burges" degipe to wan on his record. It was insisted that Burges was not really a defender of the war veterans at all because he

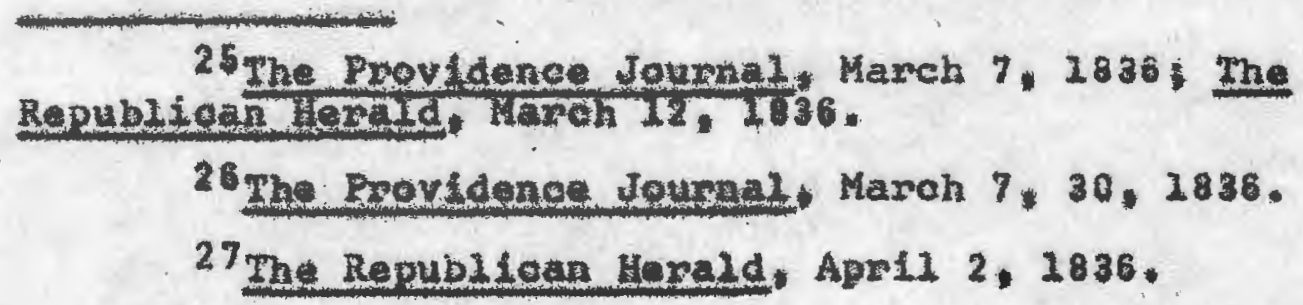


had opposed a pension for the state militias and worked minly for the benefit of the officars. The opposition felt he should not be elected because he was an avowed anti-Jackson man and would oppose the President just as he had opposed Madison during the War of 1812. To elect Bunges, moresver, would be to lefeat the national policies of tire adrinistration and allow the banks and manufacturers to control the stata.28 Late in April the Derocrats found an issue that was particularly damaging to Burges' political image. They accused him of working to establigh a Narragansett Bay maritime station for Hassachusetts on his property in Seekonk--an act virtually treasonable for a Rhode Islander. It was alleged that Burges had argued that the boundary of Massachusetts extended out into the channel of the Providence River and not only to the high water mark on the Massachusetts side as Rhode Island insisted. After drewing bleak pictures of a Narragansett Bay Clogged with Massachusetts shipping, the Denocrats effectively scoffed at Burges' denial of the charges. 29

Continuing the attack, one Denocratic paper pulled out all the stops in journalistio sensationalism to defeat Burges. Taken out of context, in dark print on the front

$$
\begin{aligned}
& 28 \text { I bid., April 9, } 1836 . \\
& 29_{\text {Ibid. }} \text { April 20, } 1836 .
\end{aligned}
$$


page, and with abselutaly no ferences, the statenonts, "I thank God that I was never a demoarat! II" and "I trust in God that I shall never see another President elected by the peoplelll" were attributed to Burges. He was publiely ridieuled in verse and again ohast1zed as unwopthy of eleetion. 30

After an insfective Whig campaign with much of the old Burges fire and oratory miesing. the Exovidence Jounal reminded its readens "TO THE poLhs, TO THE POLLS. EVERY WHIS FRDEMAK, and there deposit your vote for Tristan Burges, "31 Such a rsminder was far from suffident to ave the cleation. Outmaneuvered and outfought in the campaigh, the tid was with the Damoorats. The Whigs maged to gather only 2,584 of 7,351 votes cast, and Govemor francis was aasily reelected, 32

Although defeated twice in two years, Tristan Burges was still regarded by the Dedocmate as the most popular and the nost poverful Whig in the state. 33 He was, however, attached to a cause that had fadlen out of favor for the time belng* In less than three years he would again fill a brief but gignifleart role In the Rhode Island gubernatorlal

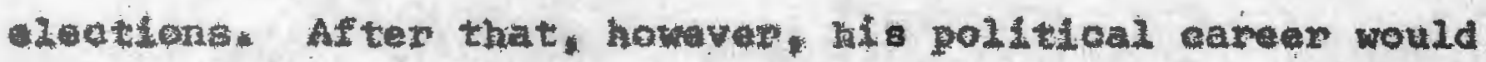
be बverp:

${ }^{30}$ Zie [Hauport] Rhode Ieland Republican. Apriz 13, 1846.

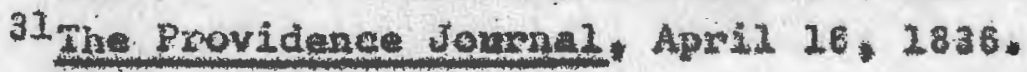

32 Hernet, Kinode Islane Manuel, p. 105.

${ }^{33}$ The Repbulfican Hera2d, Aptil $23,1836$. 


\section{THE BALD EAGLE PASSES}

Although political1y inactive for a short period after his defeat in 1836, Pristam burges played a strnificant role in the state gubernatorial elections of 1839 . At their nominating convention of that year the Whigs pledged support to the incumbent Govexnor William Sprague, Ir. and Liautenant Governor Josoph Thilds of Portsmouth. ${ }^{2}$ Sprague, who had defeated Burgas for Congress as a Denocrat in 1835 . had seen that the Democratic stand on tariff reduction was harmful to his textile interests. He renounced his party, became a Whig, and was elected Governor over the inaument John Brown Francis in 1838.2 Two other parties were opposed to Sprague's desires for reelection. The Democrat, Republican, and Fammers' Prox was led by Nathaniel Bullock of Bristol for Governor and Benjamin B. Thusston of Hopkinton For Lieutenant Govemor. Besides the two major parties a splinter group also preaented itgelf. Operating under the narae of the Liberal Party, a group of Whigs urhappy with

\footnotetext{
1 The Frovidence Journal. April 1, 1839.

2Carrol1. Rhode Island-Three Centuries of Democracy. I, 570-71.
} 
Sprague put forth Iristam Burge for Governor and Charles Collins of Midaletown for sleutenant Governor. 3

The Provigence Joumal, pamining loyal to the Whig Party. supported the nomination of the ex-Demoerat sprague and the rest of his prox. While they rowndy denounoed the Demoerats in theis usual fashion and ingled Bullock out as having been "an old hartford Convention blue light Federalist" who actively opposed the War of 1822 , they arrefully refrained from giving glmilar treatment to the Librals and sald nothing ginst their candidates personally, They 1.ined, morpover, that while Burges could not be elected. it was posible he could kep the two major andidate from gafnine the necessary majority of vote needed for electlow. If this happened the Libarals would hold the balanoe of power and could dictate the terme of compromise to ither the Demoarats on the Whiga The wigs, fearing such a move would play into the hands of the Demoorato and spell the ruin of their own party in the state, appealed for Burges to consider his old Whig bellefe and prineiples before mking ang further woves: 5

The biberal suppont of Durgea for Govemor was

IFariy Prox collection, state Archives, State house, Providenoe, Fhode Islend; Fleld, State of Rhode Iiland, I, 330 .

4he Irovidence Jouma2, Aprit 1, 1839.

Ibid: Apre12, 1839. 
apparently unsolioited, however, and its recipient uninformed. Burges had been out of Providence sinee the firat of March, and did not laam of his noination until tho sixth, when he returaed to the efty. After otudying the stuation he quickly disavowed any destre on his part to participate in the ieation:

On my retum to this atty, on Saturday evening having beon absent from it ince Monday preceding. I found in your aaliy paper Brox of General state officers with my name on of them. It will bt, I fear, in eny event imporible for the to accopt. oven undertake to discharge the duties of that office. I would state the reasons at large to you and the pubale which have Induced to write to you, but my heal th is an all suffialent reason, and which is o redued by fatigae and xhausting labor, sndured for a number of vacks past. that I cannot hold the pen to go into any detailes and ean only request that you publiah this lettar that the gentlezen who have honosud me with this nomination may be fully inforrad upon the abject.6

Although the Jourzal earided Burgat latter on the tenth of April and roprinted it in bold type on the fifted th, the sane papex continuad to wu the advartiement for the Liberal Prox with Burges as the gubernatorial cand 1date.7 While he ald no eappaigning and showed no derize to be alected the Whig feared that this continued support would eplit the electorate and defeat their bid to retain

\footnotetext{
6 Tribtam Burge to the Editors of the Currier, Providener, April 10, 1835, in tud Revidence Joumpl, Apri1 12, 1839.

7 The Rpovidence Joumal, Apwir 15-17, 1839.
} 
control of the coremor's offlce. This is estontally what happered. OI the 6,173 votas cast In the election

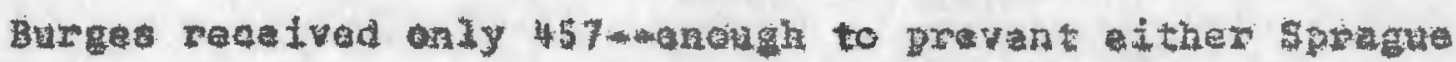
or Bullock from gaining the necesary majority. Stroe the lawn of the state did not provld for a nat alection in such alremstance, Samul ward King, the first elected Senator, becate the actidg Govemon under the provistons of the old Chartar. 9

After this bief atd walling excursion into the

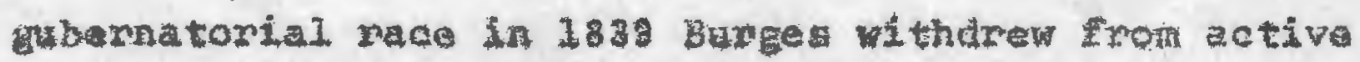
polities. Pdolving two votos as an kn-foninated candidate for the pedewal Sente by the Rhode Tsland Orand Conatte on octoba $24,1840,10$ was the find at of his political carear. His parabiag years vere spent in wetreant at the

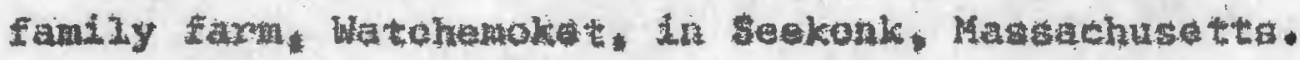

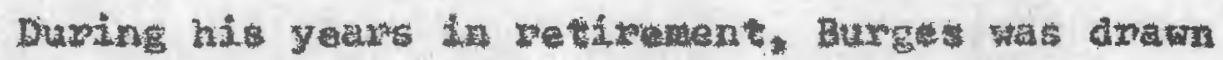
towards woligiows study and rection, perhaps latansiled by the death of all but one of his onlldren. He developed the hablt of rading from the Nen Togtament for at laast half

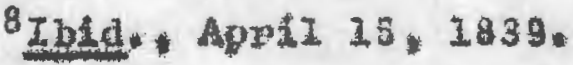

9 Bennett, Rhode Isiand Manual, D. 205. The vote was sprague, 2,308 ; Butlock, 2, T71, Burges; 457 , seat, 37 . Camolx, Rhode Istand-Tnze Centuries of Democracy, I, 570-71. At this tIne Rhode Istand was still governed under the atipulations of the old colonial Charter granted in 1663.

10Records of the House of Representatives of the State of Rhode Island Commeneing October Session, 1839 and October Session, I840. State Archivers, State House, Frovidence, Rhode IsIand Banett, Rhode Island Manual, P. 147. 
an hour before going to bed at night and spent much time meditating on the life of Jesus Christ of Nazareth. Indeed, Burges expressed the hope of writing a biography of christ in either dialogue form or as a series of letters in which Christ's life, mingled with accounts of His contemporaries and neighbors, would be portrayed. Confiding only in his wife and Reverend Thomas Willians of East Greenwich, Burges asked that no one else be informed of his desires. He also told of feeling guilty for not having gone into the minigtry as he had planned much earlier in life. Il

As he increased in age, Burges' appearances in Rhode Island were confined mainly to social events. A fellow participant described the aging ex-legislator at one meeting:

I remember the bent figure of an old man dressed in a plain gray business suit, his eyes undimmed and his mental vigor unabeted [sic]. His manner was calm, and gave no hint of the terrible force which had given him his ascendancy in the courts of Rhode Island and in the halls of Congress, but there was a pare felicity in the construction of his sentences, and his elocution was perfect. I had heard nothing like it before, nor have I heard anything to compare with it since, except when listening to Rufus Choat or Wendell Phillips.12

Whenever possible Burges attended the alumn meetings of Brown University. At one of these meetings he was called on to speak and was toasted as "The Bald Eagle of Rhode Island:

11Tristam Burges to Reverend Thomas WiIliams, Watchemoket Farm, Seekonk, Mass. August 13, 1843. Peck Mss." BoX XIII, No. 49.

12 Abraham Payne, Reminiscences of the Rhode Island Bar (Pro ldence: Tibbitts and Preston, 1885), pp. 68-9. 
may his old age be as trangull as his manhood has been glorious:" To this remark, however, lurges replied, "I do not clain to be an eagle of any kind, much less bald eagle."13 But the terra "Bald Eagle" was one that had been applied to Burges early in his Congressional career when he was violently defending the intarests of his state from the attacks of the South. Duxing his second term in Congress, 1827 to 2829 , antemporary on the Warhington soene described him:

Triatan Burgess [eia], of Rhode Island, who had a snowy head and a Reman nose, was ealled the beld eagle of the House $\mathrm{J}^{3}$.. A man of Iron heart, he was ever anxious to peet his antagonletrs, haughty in his wue telfconfidence, and exharative in the use of every expletive permitted by parilamentary usage. In debate he resembled one of the old soldiers who fought on foot and on horseback, with heavy or light arms, a battle-axe or a apear. The charipion of the Nopth he divided the South and thrashed and slashed as did old Boratios, when with his good sword he stood apon the byigge and with his single am defended Rome. 14

As the years of retirement passed, advancing age and a Iingering iliness began to take thein toll. The public appearances grew more and more lafrequent. Tristan Burges died at his home in Seekonk at half past ten on the morning of Inresday, October $13,1853.15$ he was eighty-three years

\section{Ibld. p. 69.}

14Een. Parley Poore, Penlex's Reminjseanees of Sixty Yeara in the National Metropolis (Fhiladelphat Hubbard Brothers: Publishers, 1886), $\mathrm{PP}, 81-2$.

15 ghe Men York Daliy Ifmes, Ootober is, 1853, The Providence Jountol, 00tober $14,1853$. 
old. A few days later he was laid to rest in his adopted city of Providence.

One pleasant afternoon in October a long procession moved through the oity [of Providence] to the North Burying Ground to pay the last tribute of respect to Mr. Burges. We talked on the way of the stormy career and its tranquil close. It was near the hour of sunset when the door of the tomb was closed, and to apply the words of Theodore Parker, speaking of the death of Dr. Channing, to the great Rhode Island orator: 'He and the sun went away together.116

With the passing of Tristar Burges and other similar men of his generation a political tradition was also passing away. This was the tradition established by members of the old Federalist Party who were forced to realign themselves politically when their original party had been discredited and collapaed. Burges, like many of his well eduoated and professionally successful, contemporarles, tended to gravitate into the ranks of the more conservative Hational RepublicanWhig Parties. From the time he accepted the National Republican nomination for Congress and was elected in 3825 , to the last days of his political career. Burges remained closely attached to the beliefs and ideals espoused by his nen party.

This is not to say, however, that he never swerved from the established line of the party. As his congressional career proves, Burges worked for what he considered to be in the best interests of his home state--regardless of what the majority of his party or the majority of the House members

$$
16 \text { Payne, Reminiscences, p. } 72 \text {. }
$$


thought. As indicated in his letters to his brother-in-law, he regarded the fight to preserve the protective lariff and to establish the American System as in the vital interest of his country. To this and he devoted most of his energy while in Congress. The fact that he was unwilling to accept Henry Clay's compromise measures of 1833 and denounced the Kentucky Senator as a traitor to the cause indicated the degree to which he advocated protectionism. Although this may be partly explained by his degire to aid his brother-in-law's woolen buminess, Burges' uncompromising stand on the tariff bill showed that by the mid-1830's he was advocating a political doctrine that had lost much of its forner meaning and intensity.

That Burges often put principle and personal feelings ahead of political issues is also seen in his views on slavery and the slavery controversy. Burges served in the House from 1825 to 1835 , during which time the anti-slavery movenent gradually began to transform itself. With the movement of Willian Lloyd Garrison to the North, the establishrent of the Liberato and the collapse of the gradualist emancipation societies in the boeder states, the North began a gradual swing towards a demand for innediate abolition. Despite the changes taking place around hin, Burges himself refused to become an abolitionist. Regarding slavery from a legal standpoint, he felt no emancipation shauld come without some form 
of compensation to the slave-owners. Not a "dupe" of the South, however, he inflamed Southern tempers when he advocated that the federal government had the right to act upon the logality of slavery in the territories and could prohibit it if necessary. This was a stand very sirilar to that taken by the Republicar Party twenty years later. Burges' personal feelings on slavery, however, were no longer shared by a majority of his constituents in Rhode Island. As he saw it, the difference between his position and that of his constituents was one of the major reasons for his defeat in 1835.

During his ten years in office, however, it must be conceded that Tristan Burges served his state very well. The fact that he could be elected for five successive terms, while never completely being able to rid himself of his old Federalist background, attest to his populdrity and widespread appeal. Although never able to bo elected governor of his state after retiring from Congress, despite two all-out tries, there can be Iittie doubt that Iristam Burges had earned a high place in the history of both his nation and state. Indeed, as one writer later phrased it:

A few years since, I listened to some old men who were gathered fror different parts of the country, and resting themselves on benches by the Frofile Lake, in New Hampshire [Hear Franconia Notch]. They were telling each other stories about Iristam Burges, recounting the many brilliant things he had said. Some of these anecdotes were genuine, and some of them have been floating uround the warld since the time when the Athenians were running about their city hearing and telling 
of some new thing. There could be no better proof of the unique fame of Mr. Burges. There is no surer evidence to man's pre-eminence in any walk of life than that all the good things said or done in his line are attributed to him. 17

Tristam Burges has rightly not been accorded the recognition given uen like Webster, Calhoun, Jackson, Clay, or Van Buren, for he did not dominate the national scene as did these men. To those who knew him, however, Tristam Burges was most certainly a leading member of the lesser team netionaliy, and truly a leader in his own tate. 
APPENDIX A

ELECTION RESULTS BY TOWNS FOR THE

CONGRESSIONAL ELECTIONS OF 1825

\begin{tabular}{|c|c|c|c|c|c|c|}
\hline Town & Burges & Durfee & Eddy & Pearce & Hunter & Scat'. \\
\hline Providence & 580 & 331 & 135 & 138 & 42 & 14 \\
\hline N. Providence & 91 & 18 & 35 & 39 & 1 & \\
\hline Smithfield & 141 & 173 & 102 & 70 & 6 & \\
\hline Cumberland & 124 & 125 & 96 & 93 & 5 & \\
\hline Glocester & 102 & 58 & 94 & 151 & & 5 \\
\hline Burrillville & 101 & & 61 & & 1 & 3 \\
\hline Foster & 112 & 183 & 106 & 38 & & 1 \\
\hline Scituate & 112 & 183 & 92 & 13 & & 36 \\
\hline Johnston & 43 & 148 & 48 & 3 & & 57 \\
\hline Cranston & 59 & 105 & 71 & 33 & 7 & 6 \\
\hline Warwick & 163 & 145 & 58 & 78 & 21 & 2 \\
\hline E. Greenwich & 65 & 38 & 31 & 62 & 6 & \\
\hline W. Greenwich & 94 & 100 & 40 & 38 & & \\
\hline Coventry & 131 & 26 & 115 & 227 & 6 & \\
\hline Newport & 99 & 63 & 132 & 239 & 161 & \\
\hline Portsmouth & 79 & 81 & 75 & 83 & 12 & \\
\hline Middletown & 17 & 43 & 57 & 33 & 8 & \\
\hline Tiverton & 85 & 123 & 71 & 101 & 6 & \\
\hline Little Compton & 93 & 60 & 38 & 66 & 5 & \\
\hline
\end{tabular}


APPENDIX A (continued)

\begin{tabular}{|c|c|c|c|c|c|c|}
\hline Town & Burges & Durfee & Eddy & Pearce & Hunter & Scat! \\
\hline Jamestown & 17 & 10 & 9 & 9 & 20 & \\
\hline New Shoreham & 80 & 0 & 0 & 109 & 0 & \\
\hline N. Kingstown & 67 & 55 & 127 & 107 & 32 & 20 \\
\hline S. Kingstown & 80 & 45 & 134 & 253 & 27 & \\
\hline Exeter & 68 & 73 & 96 & 93 & 2 & 1 \\
\hline Richmond & \multicolumn{2}{|c|}{$8 \mathrm{maj}$. } & & & & \\
\hline Charlestown & \multicolumn{2}{|c|}{5 maj. } & & & & \\
\hline \multicolumn{7}{|l|}{ Westerly } \\
\hline Hopkinton & \multicolumn{2}{|c|}{$10 \mathrm{maj}}$. & & & & \\
\hline Bristol & 61 & 44 & 43 & 76 & 3 & \\
\hline Warren & 37 & 5 & 52 & 84 & 6 & \\
\hline Barrington & 29 & 5 & 16 & 29 & 0 & 1 \\
\hline TOTALS & 2731 & 2260 & 1943 & 2171 & 363 & 146 \\
\hline
\end{tabular}

The Providence Gazette, September 3, 1825 . 


\section{APPENDIX B}

ELECTION RESULTS BY TOWNS FOR THE CONGRESSIONAL ELECTIONS OF 1835

\begin{tabular}{|c|c|c|c|c|c|}
\hline Town & Bunges & Cranston & Pearce & Sprague & Seat'. \\
\hline Providence & 970 & 973 & 271 & 268 & 7 \\
\hline N. Providence & 121 & 117 & 88 & 86 & \\
\hline Smithfield & 297 & 296 & 176 & 176 & \\
\hline Curaberland & 152 & 145 & 110 & $1 \times 6$ & \\
\hline joinnston & 143 & 142 & $9 x$ & 91 & \\
\hline Cranston & 75 & 74 & 122 & 124 & 1 \\
\hline Burrillville & 85 & 85 & 139 & 139 & \\
\hline Glacester & 81 & 78 & 228 & 228 & 2 \\
\hline Seituate & 79 & 69 & 232 & 231 & \\
\hline Fostex & 84 & 83 & 228 & 227 & \\
\hline Newport & 342 & 348 & 187 & 173 & \\
\hline Portsmouth & 131 & $1 \times 0$ & $9 x$ & 89 & \\
\hline Middle town & 69 & 64 & 25 & 22 & \\
\hline Little Compton & 93 & 85 & 53 & 48 & \\
\hline Tiverton & 40 & 35 & 176 & 275 & \\
\hline Jarnestown & 22 & 20 & 29 & 30 & \\
\hline New Shoreham & 34 & 32 & 112 & 110 & \\
\hline Bristol & 144 & 140 & 100 & 101 & \\
\hline Warren & 92 & 68 & 36 & 17 & \\
\hline Barrington & 47 & 47 & 24 & 24 & \\
\hline
\end{tabular}


APPEMDIX B (continued)

\begin{tabular}{lccccc}
\hline Town & Burges & Cranston & Pearce & Sprague & Scat'. \\
\hline E. Greenwich & 82 & 81 & 81 & 82 & \\
W. Greenwich & 38 & 39 & 116 & 130 & \\
Warwick & 155 & 126 & 195 & 228 & 1 \\
Coventry & 152 & 150 & 178 & 173 & \\
N. Kingstown & 43 & 37 & 195 & 194 & \\
S. Kingstown & 127 & 112 & 158 & 149 & \\
Exeter & 30 & 19 & 162 & 173 & \\
Richmond & 37 & 35 & 63 & 65 & \\
Hopkinton & 78 & 72 & 89 & 87 \\
Westerly & 72 & 69 & 79 & 72 & \\
Charlestown & 47 & 47 & 66 & 66 & 11 \\
\hline Totals & 3882 & 3675 & 3903 & 3914 \\
\hline
\end{tabular}

The Providence Journal, Auguat 31, 1835

" $x$ " incicates numbers not legible. 
APPENDIX $\mathrm{C}$

ELECRION RESULTS BY TOWNS FOR THE

GUBERNATORIAL ELECTIONS OF 1836

\begin{tabular}{|c|c|c|c|}
\hline Town & Burges & Francis & Col1ins \\
\hline Providence & 655 & 321 & 51 \\
\hline Cranston & 57 & 113 & \\
\hline Bristol & 74 & 113 & 4 \\
\hline Warren & 17 & 60 & 45 \\
\hline Johnston & 105 & 94 & 3 \\
\hline Waruick & 93 & 232 & \\
\hline Barrington & 38 & 31 & 5 \\
\hline N. Providence & 86 & 80 & 6 \\
\hline Smithrield & 171 & 235 & 5 \\
\hline Scituate & 70 & 251 & 1 \\
\hline Burrillville & 65 & 126 & \\
\hline Cumberland & 124 & 142 & 2 \\
\hline Foster & 60 & 212 & \\
\hline E. Greenwich & 34 & 123 & \\
\hline Exeter & 21 & 149 & \\
\hline N. Kingstown & 33 & 203 & \\
\hline Coventry & 128 & 190 & \\
\hline Newport & 282 & 178 & 4 \\
\hline \multirow[t]{2}{*}{ S. Kingstown } & 183 & 168 & \\
\hline & 2296 & $\begin{array}{r}3621 \\
599 \mathrm{maj} .\end{array}$ & 126 \\
\hline
\end{tabular}




\section{APPENDIX C (continued)}

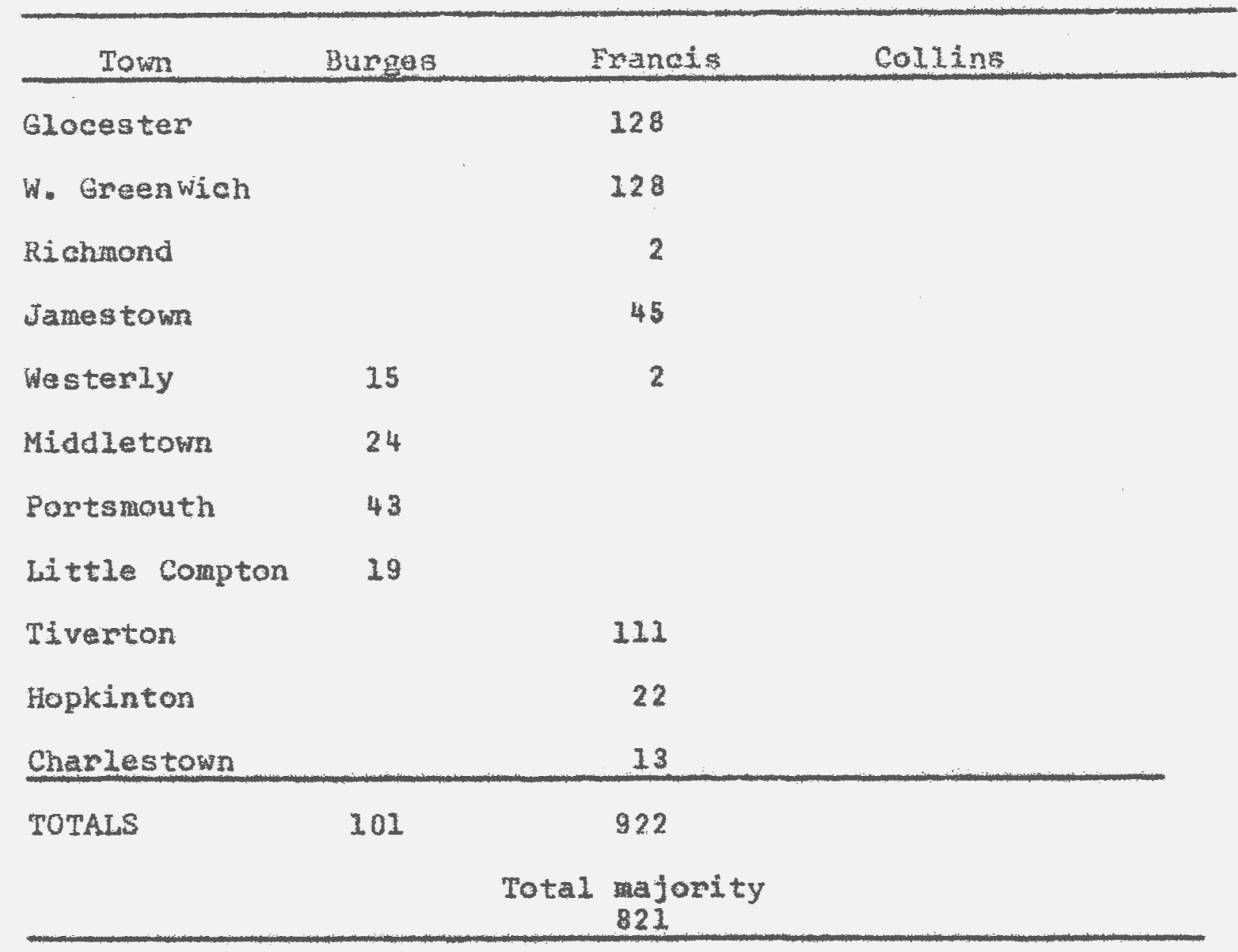

The Providence Journal, April 23, 1836 
APPENDIX D

ELECTIOH RESULTS BY TOWNS FOR THE

GUBERNATORIAL ELECTIONS OF 1839

\begin{tabular}{|c|c|c|c|}
\hline Town & Sprague & Burges & Bullock \\
\hline Providence & 605 & 243 & 232 \\
\hline N. Providence & 49 & 33 & 32 \\
\hline Cumberland & 70 & 57 & 78 \\
\hline Johnston & 96 & 11 & 54 \\
\hline Cranston & 76 & 6 & 82 \\
\hline Scituate & 56 & 2 & 123 \\
\hline Smithfield & 92 & 51 & 121 \\
\hline Burrillville & 49 & 4 & 98 \\
\hline Glocester & 59 & 17 & 124 \\
\hline Foster & 30 & 5 & 161 \\
\hline Warwick & 212 & 10 & 110 \\
\hline E. Greenwioh & 84 & 3 & 59 \\
\hline W. Greenwich & 42 & & 52 \\
\hline Coventry & $14 \overline{3}$ & & $I 3 I$ \\
\hline N. Kingstown & 54 & 5 & 130 \\
\hline S. Kingstown & 169 & & 174 \\
\hline Hopkinton & & & 54 maj. \\
\hline Charlestown & 32 & & 62 \\
\hline Exeter & 24 & & 82 \\
\hline
\end{tabular}




\section{APPENDIX D (continued)}

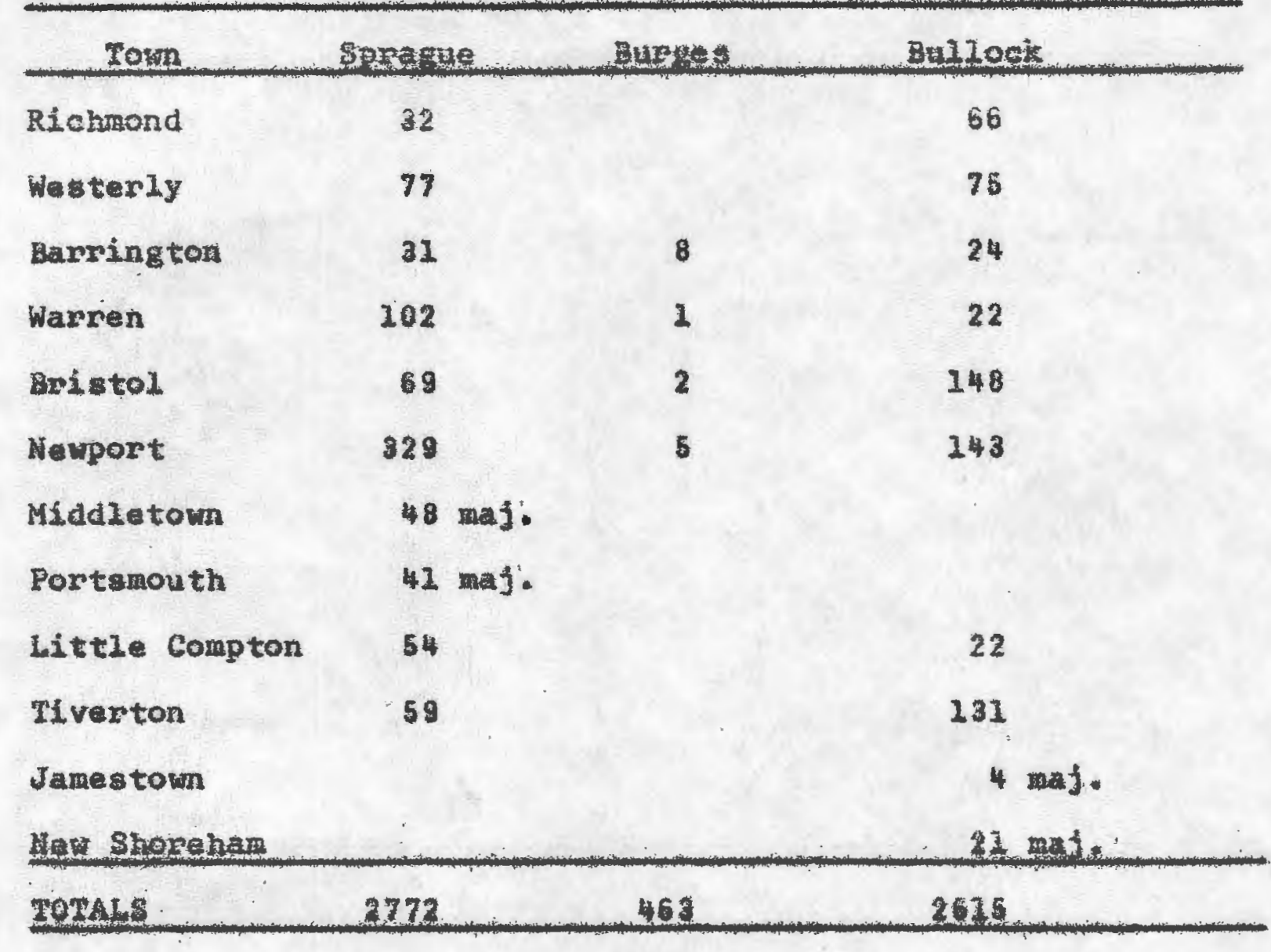

The Providance Joupaal, Apri1 20, 1839. 


\section{BIBLIOGRAPHY}

Books

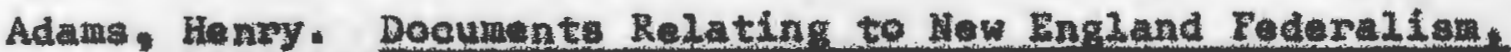

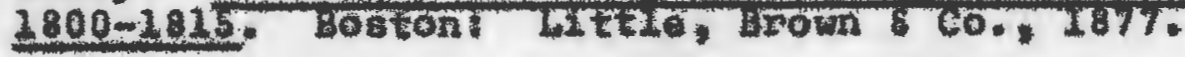

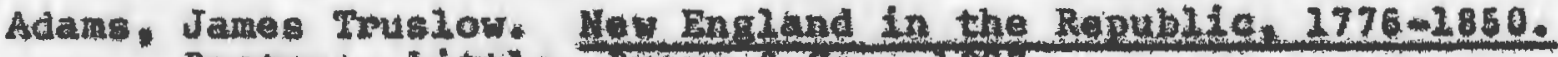
Boston! Little. Hern \& co. IMY.

Address to the Fammers of Rhode Island, on the subject of the General Election of OFIIcers. in APril, 1828. By a Farmer. Providence: H. H. Brown, 1828.

Address to the Freemen of Rhode Island, by a Freeman, Relative to the election of Representatives to Congress, Tristam Burges and Willian Sprague being Candidates. No Place: n.p. 1835 .

Address to the Friends of Domestic Industry. Assembled in Convention, at New York, Oct. 26, 1831, to the People of the United States. Baltimore: By order of the Convention, 1831 .

An Addmen to the Fremer of Rhode Ialend by a Republican

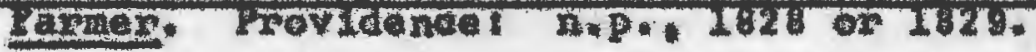

An Address to the People of Rhode Island, Proving that More than Right Milions of the PubIIC Money has been Wasted by the Present Administration. By a Landholder. Providence: Office of the RepubIican Herald, 1828.

Amold. James. Vital Recomds of ghode Ialand. Providance Narragansett tistorion Publishing $6 \%, 1894$.

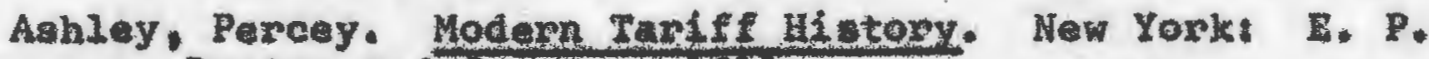
Dutton and Company, Ig11.

Auttin, John 0. Genealonieal Dietionary of Rhode IrLand.

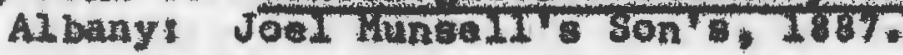

Balley. Thorad A. The Amemican Pareant. A Higtory of the Republic. Boston! D. C. Heath and Company. I956.

Bajoln, Leland D. The stream of Amorion H1story, I. Hew Yomk Amerioan book company, Igt2. 
Bancroft, Frederiek. Galhour and the South Carolina Nullifi-

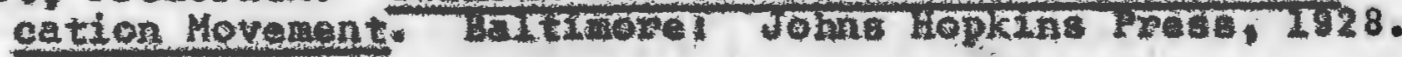

Bemis, Samuel Flagg. Johr Quingy Adans and the Union. Hew York: Alfred A Krogt: 2956.

Bennett, Charles P. Manual with Rules and Orders for the Use of the GeneraI Assembly of the state of Rhode Istand, 1909: Providence: E. Lo Freenan Company, 2909.

Binkley, Wilfred E. Amerlean Politieal Parties, Thel Natural Hietory. New Tork: AITred A. Knopf, 194t.

Biographieal Cyclopedia of Repregentative Men of Rhode Island. Frovlencet Wational biographical Pubirshing Co. 1881.

Hlau. Joseph I. (d). Jacksonian Democracy, Repregentative Writings of the Perlod, 1825-1850. Hew rork: Hafner pubissing Company, 1947 .

Bowen, Henry L. Memoin of Iristal Burges: with selections from hig speeches and Occasional Writings. Providence: Marshall, Brown, \& Co., 1855 .

Bowerg, Claude 6. The Party Battles of the Jagkgon Reriod.

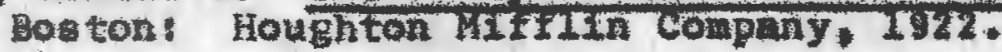

Burges, Tristas, A Brief Sketch of the Remarks Delivered at East Greenwich at a Convention of Hational Republicans, on the 23 rd of August, 1832 . Providence! Winliam Marshall and Company, 1832.

- A Statement of Some Leading Princíples Adopted by General Jackson and of the Effects of these puinoiples and Measures on the Union, Prosperity and Constitution of the American People. An Address to the Citzzens

of Rhode IsIand, in Answer to their call on the Delegation of thig state in Congress. Providence! William Marshall and Company, 1832.

- Addrens before the Rhode Itand Peace Soeiety, June

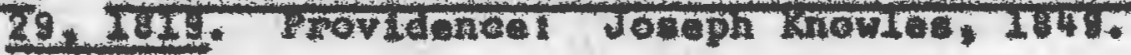
- Address to the Rhode Island Society for the EncourageMent of Domestic Industry delivered at pawtucket. October 17, 1821. Providence: Millerand Hutchins, 1822.

- Address. Slanders Refuted, being a reply to the Foul and Abusive bttacke raade on Dutee J. Pearee and rristam Burges. No place, [1829?]. 
- An Address to the Landholders and Farmers of Newport County. elivered at a keeting of the rriends of Messrs. Pearce and Burges, holden at howland s Ferry Bridge: August 7, 1829 . Providence! The Daily Advertiser, 1829.

- An Oration pronouncad before the Citizens of Providence on the fourth of July, 1831. Providence:

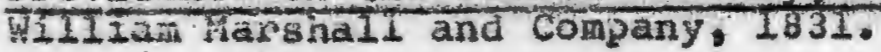

- Liberty, Glory, Union, or American Indepandence. A Fourth of vuly uretion. Providence! The khod Island American orice. 1810 .

- Reasons winy the Hon. Elisha R. Potter should not Fe a Sencior in Congress. By one of the Peorle. Providence: M.p. 1834 .

Bdimarks of Iristan Burges at the Celebration of the Fourth of Juiy in CIayville, R. I. in reply to a sentiment expressed at the dinner given on the occasion. Furnished at the solicitation of the Citizens of Clayville and Vicinity, and published at their request. Providence! the Daily Advertiser OffIce, 1829.

Remarks sent to the People who celebrated the 4 th

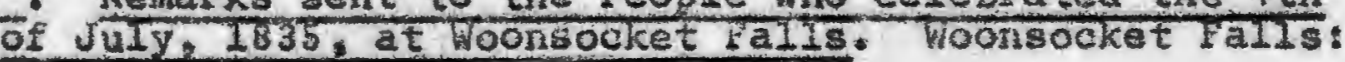
sherman है Riden 1835 .

Remarks of Mr. Burges, of Rhode Is land, In Committee of the Whole un the State of the Union, March 29,1828 , on Mr. Mallasy's irotion to Amend the 8111 on Wool. and Woolens. Ho. Place: n.P. 1828.

- Speech of Mir. Burger, of Rhode Is land, In the House of Represancatives of the United States, April 2Ist A. 0.1828 , on the handf. Washington: Way and GIdeon, 1828.

Speech of Tristam Burges in the House of Representatives of the United States, When in Committee of the whole. May 10, 1830 , on the BIII for the more effectual CoITection of the Duthes on Imports. Mr. McDuflie's Amenddent to Repeal the Tariff, Being under Conslderation. Frovidence: Merrshall and hamnond, 1830.

Speech of Mr. Burges, delievered at a Meeting of his fellow citizens, in the fown House in Providence, on Priagy evening, Mareh 3,1835 . Providence; n. P. 1835. 
Burns, Jame MacGregor. The Deadlock of Democracy: Four Party Politics in Americe. Englewood CIIfIs, N. J.: Frentice-Hall, Inc., I963.

Carroll, Charles. Rhode Is land: Three Centuries of Demospacy. I. New York: Lewis: Historieal Pubiming Co. 1932.

Chenninge Edward. A History of the United States. IV. Hev York: The Macinitin Company, 1936.

Coleman. Peter 3. The Irangformation of Rhode Islind, 1790-

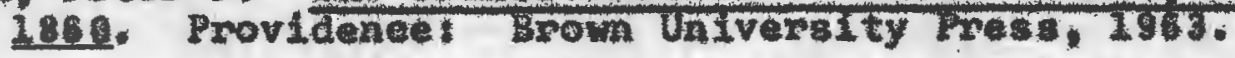

Cunningham, Noble E., Jv. The Jeffersonian Republicans in Powex, Party Operations, 1801-1809. Chapel HiII: The University of North Carolina Press, igs.

Dangerfield, George. Era of Good Feelinge. New York! Hraurt Brace, 1952.

Durfee. Thomas. Gleantngs from the Judicial History of Rhode Island. Providtace staney 5. Rider, 2883.

Dwight, Theodere. History of the Hartford Convention; With a Review of the Policy of the United states Government, Which led to the War of 1812 . New York: N. E J. White. 1833 .

Elliott, Ormin Leslie. The Tariff Controversy In the United States, $1789-1833$, With a Summary of the Period Before the Adoption of the Constitution. Palo Alto. Californial Stanford University Press, 1892.

Everett, A, H. Chaiman Memorial of the New York Convention. to the Congress of the United States, Presented March 26,1832, and Referred to the Committee on Manufactures. Boston: n.p. 1832 .

Held. Edward., ed. State of Rhode Island and Providence Plantations at the End of the Contury A kistory: IIIUstrated With Maps, Facsimiles of Old Plates and Paintings and Photographs of Ancient Landmarks. 1. Boston! The Mason Publishing Company, 1902.

General Convention, of Agriculturists and Manufacturers, and others Friendy to the Encouragement and Support of the Domestic Industry of the United States. No Place, 1. P. 1827. 
Haley, John Williarns, The old Stone Bnnk Yletory of Rhode Island, III. providence providence institution for Savings, 1938 .

Livernore, Shaw. The Twilight of Federalism; the Disintegration of the Federalist Party, 1815-1830. Princeton: Princeton University Press, 1962.

Lyoh, William 0 . Fifty Xears of Party Wefare, $1789-1837$. Ifilanapolis. Indiant the bobbsmerrill company, 1931.

Memorial of a Committee In Behalf of Cotton Manufacturers of Providence, In the State of Rhode Island, February I. 1828. Washington: Gales \& Seaton, 1828.

Memorial of the Citizens of Bristol, In the State of Rhode Island, Against an Increase of Duty on Certain Imported Manufactures, March 3 , r828. Washington: Gales है Seaton, 1828 .

Memorial of Citizens of the Town of Warren, In the State of Rhode IsIand, Against an Increase of Duty on Molasges Inported, है C., February, 25, 1328. Washington: Gales \& Seaton: 1828:

Monat, Haldor.R. The Tarift on Wool. Madson, Wisoonsin Tariff Reseaxch Combittee, 1935.

Munro, Wlifred H. The History of Britstol, Rhode Island. The Story of the Mount Hope Land, From the Visit of the rorthien to the present lime. Providence! J. A. E 2. A. Rera, 1880 .

Niles, Herekiah. Journal of the Proceedings of the Friends of Domestic Industry. In General Convention Met in the Cit of New York, Uctober 25. 1831. Baltimora: n.p.: 1831.

Payne, Abrahap. Repinisoenoes of the Rhode Island Bar. Providence: Mibitts \& Prestom, 1868.

Poore, Ben. Perley. Perley's Reminiscences of Sixty Years in the National Metropolis. Philadelphia: Hubbard Brothers, Fublishers, 1886.

Representation of Sundry Citizens of Providence, In the State Of Rhode Island, Upon the Subject of in Increased Duty on Certain Imports, March 3, 1828 . Washington: Gales

Sohlecinger. Ajthur M. Jn. The Are of Jaokeon. Erowa and Company, 1946. 
Stanwood, Edward. American Tariff Controversies in the Nineteenth Century, I. Boston! Houghton, Mifflin and company, 1903 .

Staples, W11zian R. Annals of the Town of Providence from its First Settlement, to the Organization of the city Government, in June, 1832. Providence! Knowles and Vose, 1843.

Taussig. Frunk W* The Tariff History of the United States, A Series of Essays. New Yonk! G. P. Putnam's Son's, 1901.

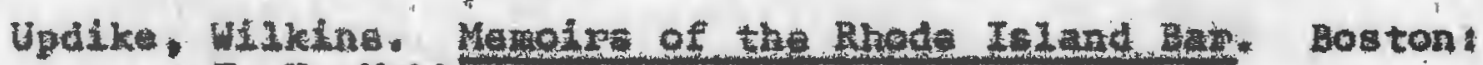
T. H. Webt E company 1642 .

\section{Covernmental Doouments und PUblestions}

The Congresmional Globe: Containing Sketches of the Debates proceedings of the Twenty-Third Congress. Vols. I E I. Washigton! orfice of the Globe, 1835.

Engrossed. Recorus of the State of Rhode Ialand. Vol. 18-19. State Archives, State House, Providence, Rhode Islane, $1809-1814,1814-1827$.

Petitions to the Rhode Island General Assembly. N.P., State

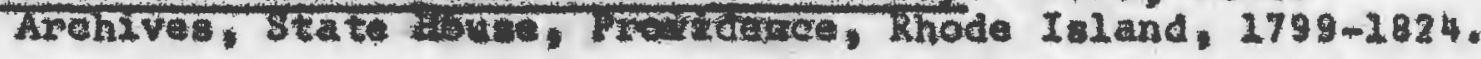

Record of the House of Representatives of the State of Rhode Island Commencing October Session, 1839 , and October Ses810n. 1840. State Arohives State House, Providence. Rhode Island.

Register of Dobutes in Conmes. NIneteenth through Twenty - Second congress. Weshington Gales seaton, $1826-1833$.

Report of the Comittee Appointed by the Genexal Assambly of Rhode IsIand to Investigate the Chardes Against Freeiasonry \& Masons in Sald State! Together with all the Official Documents and Testinony Relating to the subject. providence: Wiाlan Narshall, 1832.

Reports to the General Assembly, State of Rhode Is1and, $1810-$ 1817. N.p., State Archives, State House, Providence, Rhode Island, Ho, 88. 
Periodieals

Brown, Moses. "Offlelal Record of the Great Gale of 1815," Publications of the Rhode Island Historlcal Society. New Series, II (1894): 232-35.

"Pirst Congregational Society Pew Holders," Rhode Island History. XI, No, 2 (Apri1, 1952), 46-47.

Nlles, Hezekiah, ad. Niles Weekly Register, Containing Political, ilistorical, Geographical, Scientiflcal, Statistical. Economical and Blographical Documents, Essays and Facts, together with Motices of the Arts Manufactures and a record of the Events of the 12mes. XXXIX - XIVIII. Baltimore: By the Editor: 1828-1835.

\section{Newspapers}

The Now York Deily rimes, Detober 15, 2858.

The Proxidence Daliy Journal, 1831-1839, Oetober 15, 2853.

The Providenee Gasette and Countzy Journd, 1811-1812, 2825.

The Republican Herald (Providence), 1833-1836.

The Rhode Is land American (Providence); $1825-1829$.

The Rhode IsIand Republican (Hewport), 1836 .

\section{Unpublished Materials}

"Farly Prox Collection," State Arohives, State Eouse. Providence, Rhode Island:

Harticon, Gaxdon F. Lineal and Collateral Ancestors of Senator Theodore Francis Green who Served in the American Congress. Washington, 1955.

Langer. Kenneth Thomas. "Filsha Reymolds Potter, 8r. Pollticin - . Unpublished Master' Thenis, The UnIver:1ty of Rhode Island, Kingston, 1957 * 
Miscellaneous MSS Collection, Rhode Island Historical Society, Providence, Rhode Island.

Peck MSS Collection, Rhode Island Historical Society, Providence, Rhode island.

Potter MSS Collection, University of Rhode Island, Kingston, Rhode Island.

Renzul1i, Marx Libero. "The Extent of Rhode IEland's Partieipation in the War of $18 \mathrm{i} 2 . "$ unpubished Master's Thesis, The University of Rhode Island, Kingston, Khode Island, 1958.

Rhode IsIaad 活storical Socicty MSS Coliection, Rhode IsIand Historical Society, Providence, Rhode Island.

Shepley Papers MSS Collection, Rhode Island Historical Society Providence, Rhode Island. 